Marquette University

e-Publications@Marquette

$10-1-2014$

\title{
Investor Behavior in the Mutual Fund Industry: Evidence from Gross Flows
}

George D. Cashman

Marquette University, george.cashman@marquette.edu

Federico Nardari

University of Houston

Daniel N. Deli

DePaul University

Sriram V.Villupuram

Colorado State University - Fort Collins

Accepted version. Journal of Economics and Finance, Vol. 38, No. 4 (October 2014): 541-567. DOI. (C) 2014 Springer Nature Switzerland AG. Part of Springer Nature. Used with permission.

Sharable link, provided by the Springer Nature SharedIt content-sharing initiative.

George Cashman was affiliated with Texas Tech University at the time of publication.

Shareable Link. Provided by the Springer Nature SharedIt content-sharing initiative. 
Marquette University

\section{e-Publications@Marquette}

\section{Finance Faculty Research and Publications/College of Business Administration}

This paper is NOT THE PUBLISHED VERSION; but the author's final, peer-reviewed manuscript. The published version may be accessed by following the link in the citation below.

Journal of Economics and Finance, Vol. 38, No. 1 (2014): 541-567. DOI. This article is (C) Springer and permission has been granted for this version to appear in e-Publications@Marquette. Springer does not grant permission for this article to be further copied/distributed or hosted elsewhere without the express permission from Springer.

\section{Investor Behavior in the Mutual Fund Industry: Evidence from Gross Flows}

George D. Cashman

Texas Tech University, Lubbock, TX

Federico Nardari

University of Houston, Houston, TX

Daniel N. Deli

DePaul University Chicago, IL

Sriram V. Villupuram

Colorado State University, Fort Collins, CO

Table of Contents

1 Introduction

2 Data 


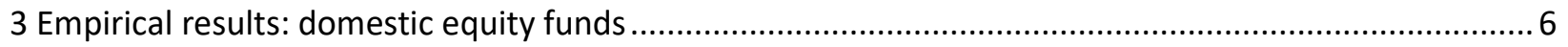

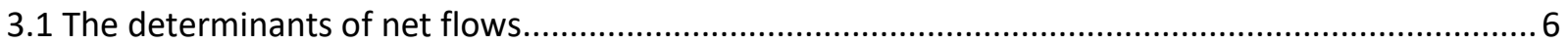

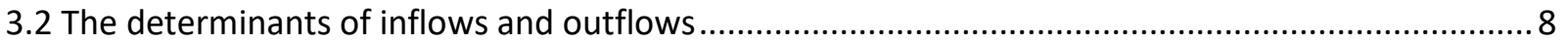

3.3 Comparing the relative effects of performance and persistence ................................................... 11

3.4 Comparing the relative persistence across flow types ............................................................. 13

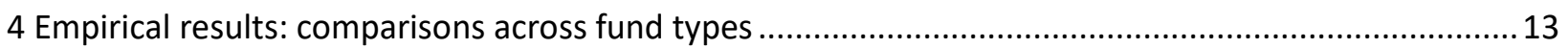

4.1 The performance flow relation across fund types ................................................................... 14

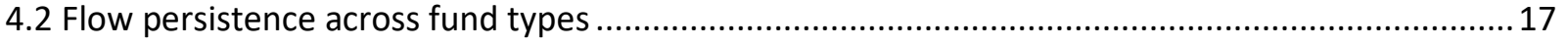

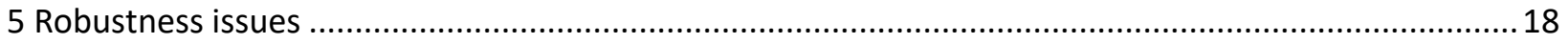

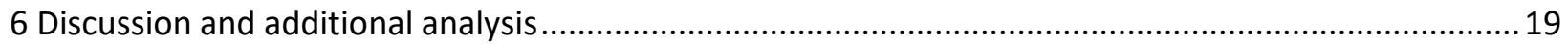

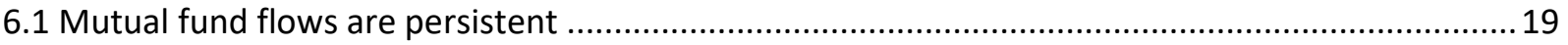

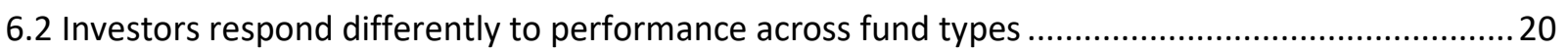

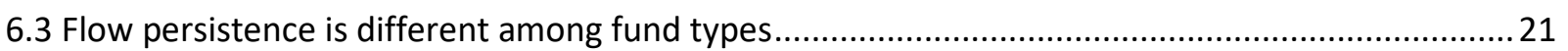

6.4 Investors respond to performance over shorter windows ........................................................... 21

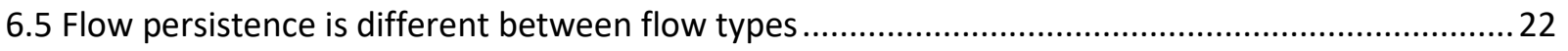

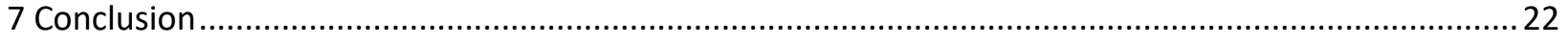

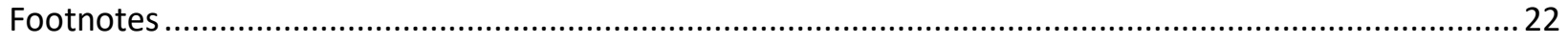

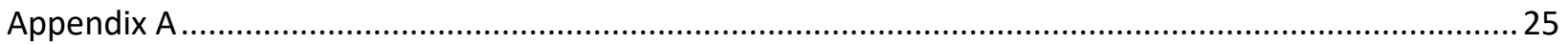

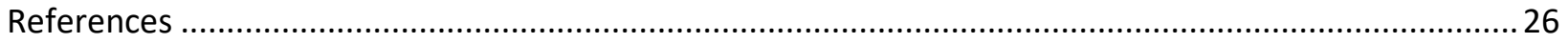

\section{Introduction}

Net cash flows into equity mutual funds have increased from $\$ 7$ billion in 1985, to $\$ 124$ billion in 1995, and to $\$ 136$ billion in 2005 (Investment Company Institute (2006)). During that same time period inflows (outflows) rose from $\$ 40$ (\$33) billion to $\$ 434(\$ 309)$ billion to $\$ 1,210(\$ 1,074)$ billion. Although extensive research has been conducted on the determinants of net flows, relatively little research has been conducted on the determinants of inflows and outflows. This relative lack of research is startling given that, as one can infer from the figures above, gross flows tend to be several times larger than net flows, and examining gross flows allows for a richer understanding of investor behavior.

Johnson (2007) argues that beyond gaining a better understanding of investor behavior, examining gross flows is important because of the potential effect of gross flows on performance. Edelen (1999) shows that inflows and outflows, to the extent that they do not offset one another, cause funds to engage in (liquidity motivated) trading that they otherwise would have avoided. Edelen (1999) and Alexander et al. (2007) show that liquidity motivated trading is costly to long-term fund investors. Thus, both fund managers and investors have an interest in understanding the dynamics that drive inflows and outflows. 
Investor behavior can also affect advisor incentives with respect to risk. Chevalier and Ellison (1997) note that mutual fund advisor compensation is typically tied to funds under management which implies that investor flows serve as an implicit incentive mechanism. Brown et al. (1996) and Chevalier and Ellison (1997) argue that compensation tied to funds under management and the convex relation between performance and flows combine to create incentives for managers to alter fund risk within a year conditional on performance in the first part of the year. Johnson (2007) contends that if existing investors are less sensitive to poor performance than they are to good performance (i.e., they purchase more shares in response to good performance than they sell in response to poor performance), then the manager's incentive to shift risk is even greater than previously assumed. In other words, the relative lack of responsiveness of existing investors to poor performance leads to an incentive for fund managers to exploit existing fund investors. Examining gross flows allows us to examine this issue directly.

We investigate the dynamics of gross flows, examining the role of flow persistence and fund performance. This allows us to make three contributions to the existing literature. First, we document the importance of persistence in monthly flows.1 Second, we document differences in investor behavior across fund types. Third, we provide evidence on the relation between performance and flows at the monthly frequency.

We find that mutual fund flows are highly persistent. This is true regardless of whether we are considering inflows, outflows, or net flows. Prior research on gross flows has either not focused on the role of persistence in inflows and outflows (Bergstresser and Poterba (2002), Johnson (2007) and Keswani and Stolin (2008)) or uses a sample construction algorithm that excludes persistence from the sample (Ivkovich and Weisbenner (2006)).2 Thus, our results on flow persistence represent new evidence on an important aspect of investor behavior. Namely, the importance of persistence suggests that investors do not completely re-evaluate their mutual fund selection each month.

Second, we document economically important differences in investor behavior across fund types. Prior studies on mutual fund flows focus almost exclusively on (large) domestic equity funds. We find that hybrid fund investors are much less sensitive to fund performance than are investors in domestic or international equity funds.3 Borrowing Johnson's (2007) verbiage, this result suggests that equity fund investors are more active monitors of fund performance than hybrid fund investors. We also find differences in flow persistence. Specifically, gross flows are more persistent in international equity funds then they are in domestic equity funds, which are, in turn, more persistent than gross flows in hybrid funds. These results suggest that there are meaningful differences in investors across fund types, which might induce important variation in fund advisor incentives.

Third, and perhaps most obviously, we extend prior research by providing evidence on the relation between performance and net flows at the monthly frequency. Large-sample analysis of the performance flow relation at the monthly interval is largely absent. 4 We find that net flows respond both contemporaneously and with a lag to fund performance-with the lagged effect diminishing over the next twelve months.5 Together, these results suggest that at least some investors evaluate and respond to performance over windows shorter than previously identified. This is potentially important to the debate regarding how investors' reaction to annual performance creates incentives for advisors to manipulate risk within a year. To the extent that investors evaluate and respond to performance over periods shorter than a year, the incentive for the advisor to manipulate risk within the year is diminished. 
The rest of the paper proceeds as follows. Section 2 describes the sample and provides preliminary analysis. Section 3 presents the empirical results for domestic equity funds. Section 4 extends the analysis to international equity funds and domestic hybrid funds and provides comparisons across fund types. In Section 5, we assess the robustness of our main empirical findings. In Section 6, we discuss the main implications of our results. Section 7 concludes.

\section{Data}

\subsection{Flow and return variables}

We construct our sample from investment company N-SAR filings with the Securities and Exchange Commission (SEC) and the Center for Research in Security Prices Survivor Bias Free Mutual Fund Database (hereafter referred to as CRSP). Mutual funds file two N-SARs per year, each covering a sixmonth time period. We collect all N-SARs pertaining to calendar years 1997 through 2003. However, the $\mathrm{N}$-SAR filings do not contain a unique and consistent fund identifier. Therefore, we are forced to manually compare various identifiers on each filing to create each fund's filing time series. Once we have created our time series of N-SAR filings we then manually compare family and fund names between the N-SAR filing and the CRSP database to form our sample. Our initial sample contains 265,750 fund month observations for the period of April 1997 through June 2003.6

N-SAR filings identify the dollar amount of investor purchases, and sales for each of the six months covered by the filing. We define net flows as investor purchases minus investor sales divided by the fund's size at the beginning of the month. Inflows and outflows are defined similarly. However, N-SAR filings do not require funds to specify total net assets each month, so we infer monthly total net assets from the N-SAR reported total net assets and the monthly returns provided by CRSP.7 One aspect of NSAR data that is different from that found in other studies is that it is at the fund level, not at the shareclass level. Thus, our measures of flows capture all flows across the various classes of fund shares (if there are multiple share classes).

From the initial panel of 265,750 fund-months we eliminate observations that appear to contain a data entry error. Specifically, we eliminate observations with: monthly net flows greater the $50 \%$, or less than $-12 \%$ of assets, monthly inflows greater than $50 \%$ or less than $0.05 \%$ of assets, and monthly outflows greater than $50 \%$ of less than $0 \%$ of assets, as these observations represent extremely unlikely monthly flows. This results in a loss of 52,112 fund month observations. 8 Additionally, we remove observations with an effective expense ratio, a redemption fee, or a $12 b-1$ fee above $2 \%$, or an effective front-end load, or deferred sales fee above $7 \%$. We remove these observations as they potentially result from data entry issues, or potentially erroneous matches between the datasets. Lastly, we remove all international debt and specialty funds from the sample, leaving a total sample of 148,126 fundmonth observations.9 The funds range in size from a maximum of $\$ 105$ billion to a minimum of less than $\$ 1$ million with a mean (median) size of $\$ 961$ (\$98) million. While we remove a sizeable portion of our initial sample, we are left with a sample considerable larger than other papers that match these two databases, such as Christoffersen et al. (2005) which reports a sample of 98,352 fund month observations.

We measure fund performance using abnormal (or, risk-adjusted) returns, which we define as raw return minus expected return.10 For domestic equity funds, we calculate expected returns using the Carhart four-factor model.11 We calculate expected returns for international equity funds, using a 
global market index, and a currency index.12 This is similar to the approach adopted, among others, by Dumas and Solnik (1995) as well as DeSantis and Gerard (1998). For hybrid funds, we calculate expected returns using the Chen et al. (2008) equity and bond factors.13 For each expected return methodology we estimate each fund's factor loadings using a 36 month rolling estimation window. Fortunately, as none of the expected returns models utilize N-SAR data the 36 month estimation wind does not materially affect the size of our sample.

Lastly, we collect each fund's Standard and Poor's classification. We classify funds based on the Standard and Poor's Objective Code provided by CRSP (see Appendix A for the list of fund types in each category). Table 1 shows the number of funds in each category in our sample, through time. We see that the number of domestic equity funds initially increases, reaching a maximum in 2001, and then declines in 2002 and 2003. Table 1 also shows a similar pattern for international equity and hybrid funds.

Table 1 Sample description

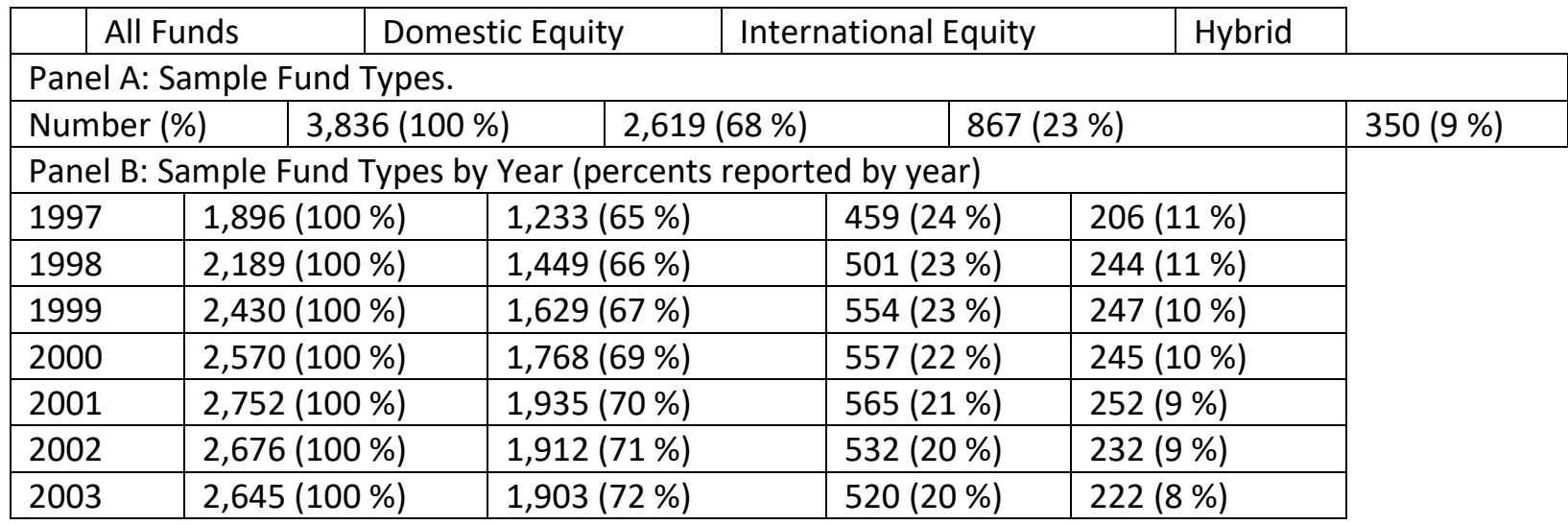

Our data are from the SEC's Electronic Data Gathering and Retrieval (EDGAR) website. The source is investment company form N-SAR, and the CRSP Survivor-Bias-Free US Mutual Fund Database. We collect N-SARs filed between April 1997 and June 2003 for equity funds and then match these filings to CRSP. We use the Standard \& Poor's Objective Code to determine whether the fund invests in domestic equity, international equity, or whether the fund is a hybrid fund. The mapping into these broad classifications is presented in Appendix A. Panel A presents the general breakdown of funds in our sample. Panel B presents the breakdown of fund types year by year

\subsection{Control variables}

Sirri and Tufano (1998) find that annual net flows are related to fund expenses, $12 \mathrm{~b}-1$ fees, and suggest the need to control for a fund's overall risk. As a result, we control for the fund's expense ratio, the level of its $12 \mathrm{~b}-1$ fee, and the standard deviation of the fund's abnormal monthly returns. Additionally, Nanda et al. (2009) find that cash flow volatility increases with the introduction of multiple fund share classes. Therefore, we use an indicator variable to capture the presence of multiple share classes.

We also control for mutual fund fees (front-end loads, contingent deferred sales charges, and redemption fees) as they might affect the level of inflows and outflows. We compute effective measures for each type of trading fee using the dollar amount collected due to each type of trading fee divided by the total amount of trading that could have possibly been subject to that fee. For example, to calculate our measure of effective front-end loads we divide the amount of front-end load fees collected by the total amount of inflows during the six-month reporting period. Using this methodology, we calculate effective front-end loads, effective back-end loads, and effective redemption fees (we use the same 
value for each of the six months covered by a particular N-SAR filing). For a fund with a single share class the effective load represents the loads paid by investors. However, when a fund offers multiple share classes, each class is subject to its own fee and load structure. For these funds, the effective loads represent what the average investor in the fund actually paid. We do not believe this to be a significant limitation as in unreported tests we find qualitatively similar results when we examine the single share class funds and multiple share class funds sub-sample independently.

\section{Empirical results: domestic equity funds}

In this section, we examine the determinants of net flows as well as inflows and outflows to domestic equity funds. We follow that analysis by comparing the relative effects of performance and persistence on fund flows. Finally, we consider the relative persistence of flows across different flow types.14

\subsection{The determinants of net flows}

We examine the determinants of monthly net flows in Table 2. Using the Fama and MacBeth (1973) methodology we report results for three different performance flow specifications-column 1 includes only prior returns, column 2 includes only lagged net flows, and column 3 includes both lagged returns and lagged flows.15 Each specification includes our control variables. In the first and third specifications, we see that net flows are positively related to contemporaneous and lagged returns. These results suggest that investors react to fund performance as it happens, but also for many months to come. Specifically, the results in Table 2 suggest that returns in any given month affect subsequent net flows for the next 12 months. 16

Table 2 The determinants of net flows to domestic equity funds

\begin{tabular}{|l|l|l|l|}
\hline & $(1)$ & $(2)$ & $(3)$ \\
\hline AbReturn t & $0.128^{* *}(7.63)$ & & $0.102^{* *}(8.25)$ \\
\hline AbReturn t-1 & $0.133^{* *}(8.28)$ & & $0.094^{* *}(8.14)$ \\
\hline AbReturn t-2 & $0.102^{* *}(7.67)$ & & $0.058^{* *}(5.60)$ \\
\hline AbReturn t-3 & $0.126^{* *}(9.97)$ & & $0.071^{* *}(6.54)$ \\
\hline AbReturn t-4 & $0.109^{* *}(9.43)$ & & $0.050^{* *}(4.70)$ \\
\hline AbReturn t-5 & $0.103^{* *}(7.53)$ & & $0.040^{* *}(3.87)$ \\
\hline AbReturn t-6 & $0.096^{* *}(5.60)$ & & $0.023^{*}(2.05)$ \\
\hline AbReturn t-7 & $0.113^{* *}(6.45)$ & & $0.038^{* *}(2.78)$ \\
\hline AbReturn t-8 & $0.108^{* *}(6.62)$ & & $0.039^{* *}(2.74)$ \\
\hline AbReturn t-9 & $0.128^{* *}(7.53)$ & & $0.015(1.57)$ \\
\hline AbReturn t-10 & $0.130^{* *}(7.91)$ & & $0.023^{*}(2.47)$ \\
\hline AbReturn t-11 & $0.123^{* *}(8.84)$ & & $0.042^{* *}(3.43)$ \\
\hline AbReturn t-12 & $0.113^{* *}(7.42)$ & & $0.030^{* *}(2.74)$ \\
\hline NetFlow t-1 & & $0.285^{* *}(18.36)$ & $0.240^{* *}(14.62)$ \\
\hline NetFlow t-2 & & $0.145^{* *}(14.65)$ & $0.135^{* *}(13.05)$ \\
\hline NetFlow t-3 & & $0.100^{* *}(10.86)$ & $0.097^{* *}(9.56)$ \\
\hline NetFlow t-4 & & $0.060^{* *}(6.52)$ & $0.069^{* *}(7.14)$ \\
\hline NetFlow t-5 & & $0.040^{* *}(6.03)$ & $0.043^{* *}(6.08)$ \\
\hline NetFlow t-6 & & $0.044^{* *}(5.69)$ & $0.042^{* *}(4.76)$ \\
\hline NetFlow t-7 & & $0.012(1.86)$ & $0.017^{*}(2.49)$ \\
\hline NetFlow t-8 & & & $0.003(0.46)$ \\
\hline
\end{tabular}




\begin{tabular}{|l|l|l|l|}
\hline NetFlow t-9 & & $0.010(1.25)$ & $0.017(1.85)$ \\
\hline NetFlow t-10 & & $-0.019^{*}(-2.63)$ & $-0.013(-1.53)$ \\
\hline NetFlow t-11 & & $-0.020^{* *}(-2.67)$ & $-0.017^{*}(-2.14)$ \\
\hline NetFlow t-12 & & $0.053^{* *}(5.42)$ & $0.072^{* *}(5.99)$ \\
\hline Multiclass & $0.002^{* *}(4.81)$ & $0.000(0.58)$ & $0.001(1.37)$ \\
\hline InSize & $-0.003^{* *}(-24.12)$ & $-0.001^{* *}(-11.38)$ & $-0.001^{* *}(-12.76)$ \\
\hline StdRet & $0.234(0.94)$ & $0.464^{*}(2.06)$ & $0.256(1.32)$ \\
\hline ExpenseRatio & $-1.687^{* *}(-22.18)$ & $-0.814^{* *}(-13.97)$ & $-0.600^{* *}(-10.85)$ \\
\hline EffectiveFrontLoad & $0.100^{* *}(4.75)$ & $0.008(0.49)$ & $0.004(0.31)$ \\
\hline EffectiveRedemptionFee & $1.655^{* *}(3.72)$ & $0.446(1.67)$ & $0.632(1.45)$ \\
\hline EffectiveCDSC & $0.353^{* *}(5.90)$ & $0.140^{*}(2.26)$ & $0.083(1.44)$ \\
\hline $12 \mathrm{~b}-1$ Fee & $1.380^{* *}(7.82)$ & $0.360^{* *}(3.28)$ & $0.402^{* *}(3.25)$ \\
\hline Adj-R2 & 0.1407 & 0.3722 & 0.3930 \\
\hline
\end{tabular}

This table presents results from Fama MacBeth regressions on our sample of 2,619 domestic equity mutual funds. There are 103,645 fund month observations from April 1997 to June 2003. The dependent variable is net flow, which is the amount of new money invested in the fund minus the amount of money withdrawn from the fund over a month, divided by the size of the fund at the beginning of the month. The independent variables are AbReturns, which are Fama-French four factor adjusted returns (where the adjustment is based on rolling betas estimates over the prior 36 months). NetFlows are lagged values of the dependent variable. LnSize is the natural log of the fund's total net asset at the beginning of the month. StdRet is the standard deviation of the fund's abnormal monthly returns over the previous 12 months. Expense Ratio is the expense ratio over the six month N-SAR reporting period. Effective Front Load is the money that the fund collected from the front-end load over the six month reporting period divided by the amount of new money flowing into the fund over the same six month reporting period. Effective Redemption Fee is the money generated from the fund's redemption fee over the six month reporting period divided by the amount of money withdrawn from the fund during the same six month reporting period. Effective CDSC is the money collected from the fund's contingent deferred sales charges over the six month reporting period divided by the amount of money withdrawn from the fund during the same six month reporting period. $12 \mathrm{~b}-1$ Fee is the money generated for the fund from 12-b1 fees over the six month reporting period divided by the size of the fund at the time of the N-SAR filing. ${ }^{* *}$ indicates significance at the $1 \%$ level. * indicates significance at the $5 \%$ level

It is interesting to note the differences in the lagged return coefficients across specifications. When we do not include lagged net flows in the regression, the coefficients on all twelve lags of performance are relatively constant (ranging from 0.102 to 0.133 ).17 When we include lagged net flows two patterns emerge. First, the coefficients on lagged returns are systematically lower. Second, the differences appear to be increasing for longer return lags. In other words, including lagged flows has little effect on contemporaneous returns, but is increasing thereafter. For example, the difference between the coefficients on contemporaneous returns is -0.026 . For the six, seventh, and eighth lags of net flows the difference increases to $-0.073,-0.075$, and -0.069 , respectively. Including lagged net flows in the analysis appears to create an economically significant reduction in the lagged return coefficients, while the inclusion of lagged returns has no effect on the lagged flows coefficient.

When we examine our adjusted-R2s, the differences are striking, and suggest a central role for prior net flows in determining future net flows. When we only include lagged returns the R2 is approximately $14 \%$ compared to $37 \%$ when we include only lagged net flows. When we include lagged returns with 
lagged flows the R2 increases to $39 \%$, suggesting that lagged returns offer little incremental value in explaining net flows over lagged flows. These results suggests the central role of flow persistence, and suggests that any research considering the determinants of monthly fund flows should take into account prior fund flows.

We interpret the evidence presented in Table 2 as suggesting that net flows respond to monthly performance, both contemporaneously and over time with the effect diminishing over time. This is important as it suggests that while prior research has focused on annual performance, some portion of investors respond to monthly performance. Additionally, the results of Table 2 provide a first glimpse into the importance of flow persistence in determining mutual fund flows.

\subsection{The determinants of inflows and outflows}

As mentioned previously, early research on mutual fund flows focuses almost entirely on annual net flows. More recently, research has moved towards considering the determinants of gross flows (Bergstresser and Poterba (2002), and Johnson (2007)). Examining inflows and outflows is relevant because it gives us a richer understanding of mutual fund investors.

As one might expect given our earlier results, the first regression of Table 3 shows that inflows are positively related to contemporaneous and lagged performance. As was the case with net flows, we observe considerable persistence in mutual fund inflows. In the second regression of Table 3, a $10 \%$ increase in inflows one month suggests a $3.92 \%$ increase in inflows during the following month. All told, inflows appear to be persistent for up to six months.

Table 3 Determinants of inflows to domestic equity funds

\begin{tabular}{|l|l|l|l|}
\hline & $(1)$ & $(2)$ & $(3)$ \\
\hline AbReturn t & $0.124^{* *}(6.46)$ & & $0.100^{* *}(8.60)$ \\
\hline AbReturn t-1 & $0.146^{* *}(8.30)$ & & $0.082^{* *}(7.58)$ \\
\hline AbReturn t-2 & $0.129^{* *}(8.56)$ & & $0.046^{* *}(4.60)$ \\
\hline AbReturn t-3 & $0.134^{* *}(9.35)$ & & $0.046^{* *}(4.05)$ \\
\hline AbReturn t-4 & $0.124^{* *}(8.53)$ & & $0.037^{* *}(3.34)$ \\
\hline AbReturn t-5 & $0.106^{* *}(6.62)$ & & $0.019^{*}(1.98)$ \\
\hline AbReturn t-6 & $0.107^{* *}(6.30)$ & & $0.002(0.13)$ \\
\hline AbReturn t-7 & $0.113^{* *}(5.88)$ & & $0.015(1.31)$ \\
\hline AbReturn t-8 & $0.087^{* *}(4.99)$ & & $0.009(0.75)$ \\
\hline AbReturn t-9 & $0.109^{* *}(5.97)$ & & $-0.003(-0.29)$ \\
\hline AbReturn t-10 & $0.112^{* *}(6.37)$ & & $0.010(1.09)$ \\
\hline AbReturn t-11 & $0.104^{* *}(6.75)$ & & $0.014(1.52)$ \\
\hline AbReturn t-12 & $0.101^{* *}(6.51)$ & & $0.015(1.73)$ \\
\hline Inflow t-1 & & $0.392^{* *}(23.08)$ & $0.371^{* *}(19.90)$ \\
\hline Inflow t-2 & & $0.173^{* *}(17.40)$ & $0.176^{* *}(14.97)$ \\
\hline Inflow t-3 & & $0.100^{* *}(9.54)$ & $0.101^{* *}(9.01)$ \\
\hline Inflow t-4 & & $0.050^{* *}(6.30)$ & $0.069^{* *}(6.88)$ \\
\hline Inflow t-5 & & $0.027^{* *}(3.57)$ & $0.029^{* *}(3.04)$ \\
\hline Inflow t-6 & & $0.058^{* *}(7.37)$ & $0.051^{* *}(4.94)$ \\
\hline Inflow t-7 & & $0.002(0.21)$ & $-0.000(-0.03)$ \\
\hline Inflow t-8 & & & $-0.000(0.01)$ \\
\hline
\end{tabular}




\begin{tabular}{|l|l|l|l|}
\hline Inflow t-9 & & $-0.003(-0.37)$ & $0.008(0.87)$ \\
\hline Inflow t-10 & & $-0.009(-1.31)$ & $-0.018^{*}(-2.33)$ \\
\hline Inflow t-11 & & $-0.012(-1.88)$ & $-0.010(-1.34)$ \\
\hline Inflow t-12 & & $0.063^{* *}(5.93)$ & $0.078^{* *}(6.22)$ \\
\hline Multiclass & $0.004^{* *}(7.31)$ & $0.001(1.30)$ & $0.001(1.45)$ \\
\hline InSize & $-0.003^{* *}(-15.82)$ & $-0.001^{* *}(-8.25)$ & $-0.001^{* *}(-9.51)$ \\
\hline StdRet & $3.629^{* *}(10.34)$ & $0.888^{* *}(3.94)$ & $0.758^{* *}(4.06)$ \\
\hline ExpenseRatio & $-1.082^{* *}(-14.97)$ & $-0.444^{* *}(-9.21)$ & $-0.313^{* *}(-6.20)$ \\
\hline EffectiveFrontLoad & $-0.395^{* *}(-14.67)$ & $-0.095^{* *}(-5.84)$ & $-0.084^{* *}(-5.21)$ \\
\hline EffectiveRedemptionFee & $4.368^{* *}(5.72)$ & $0.201(0.74)$ & $0.355(0.74)$ \\
\hline EffectiveCDSC & $-0.277^{* *}(-4.26)$ & $-0.070(-1.03)$ & $-0.107(-1.66)$ \\
\hline 12b-1 Fee & $2.179^{* *}(14.07)$ & $0.338^{* *}(3.17)$ & $0.393^{* *}(3.28)$ \\
\hline Adj-R2 & 0.1165 & 0.5186 & 0.5547 \\
\hline
\end{tabular}

This table presents results from Fama MacBeth regressions on our sample of 2,619 domestic equity mutual funds. There are 103,645 fund month observations from April 1997 to June 2003. The dependent variable is inflow, which is the amount of new money invested in the fund over a month, divided by the size of the fund at the beginning of the month. The independent variables are AbReturns, which are Fama-French four factor adjusted returns (where the adjustment is based on rolling betas estimates over the prior 36 months). Inflows are lagged values of the dependent variable. LnSize is the natural log of the fund's total net asset at the beginning of the month. StdRet is the standard deviation of the fund's abnormal monthly returns over the previous 12 months. Expense Ratio is the expense ratio over the six month N-SAR reporting period. Effective Front Load is the money that the fund collected from the frontend load over the six month reporting period divided by the amount of new money flowing into the fund over the same six month reporting period. Effective Redemption Fee is the money generated from the fund's redemption fee over the six month reporting period divided by the amount of money withdrawn from the fund during the same six month reporting period. Effective CDSC is the money collected from the fund's contingent deferred sales charges over the six month reporting period divided by the amount of money withdrawn from the fund during the same six month reporting period. $12 b-1$ Fee is the money generated for the fund from 12-b1 fees over the six month reporting period divided by the size of the fund at the time of the N-SAR filing. ${ }^{* *}$ indicates significance at the $1 \%$ level. ${ }^{*}$ indicates significance at the $5 \%$ level

When we include lagged returns and lagged inflows in the analysis, however, we see that the performance results change (as they did for net flows). Specifically, rather than being related to contemporaneous performance and prior twelve months performance, we see that only contemporaneous and prior five months of returns are significantly related to current inflows. Again, note that when lagged flows are included, the magnitudes of the performance coefficients decline appreciably. For example, in going from the first regression to the third regression the coefficients on one and two-month lagged returns drop from 0.146 and 0.129 to 0.082 and 0.046 , respectively, while the inclusion of lagged returns has little effect on the lagged inflow coefficients. In other words, flow persistence appears to play a more important role in determining future fund inflows than fund performance.

We next report results for the determinants of outflows in Table 4.18 Unlike net flows and inflows, there is little evidence of a meaningful relation between performance and outflows. Only the coefficient on eight-month lagged returns is statistically significant, but it is quite small. As with net flows and inflows we do find evidence that outflows are persistent. 
Table 4 Determinants of outflows to domestic equity funds

\begin{tabular}{|c|c|c|c|}
\hline & $(1)$ & (2) & (3) \\
\hline AbReturn $\mathrm{t}$ & $0.004(0.36)$ & & $0.012(1.92)$ \\
\hline AbReturn t-1 & $-0.014(-1.21)$ & & $0.002(0.28)$ \\
\hline AbReturn t-2 & $-0.028 * *(-2.75)$ & & $-0.008(-1.33)$ \\
\hline AbReturn t-3 & $-0.008(-0.85)$ & & $0.008(1.22)$ \\
\hline AbReturn t-4 & $-0.015(-1.48)$ & & $-0.002(-0.30)$ \\
\hline AbReturn t-5 & $-0.003(-0.30)$ & & $0.004(0.64)$ \\
\hline AbReturn t- 6 & $-0.012(-1.06)$ & & $0.007(1.14)$ \\
\hline AbReturn t-7 & $0.000(0.01)$ & & $0.008(1.29)$ \\
\hline AbReturn t-8 & $0.021 * *(2.20)$ & & $0.014 *(2.16)$ \\
\hline AbReturn t-9 & $0.019(1.79)$ & & $0.001(0.16)$ \\
\hline AbReturn t-10 & $0.018(1.54)$ & & $0.001(0.11)$ \\
\hline AbReturn t-11 & $0.020(1.93)$ & & $0.008(1.33)$ \\
\hline AbReturn t-12 & $0.012(1.00)$ & & $-0.003(-0.41)$ \\
\hline Outflow t-1 & & $0.383 * *(32.16)$ & $0.386 * *(31.68)$ \\
\hline Outflow t-2 & & $0.171 * *(16.83)$ & $0.177^{* *}(16.49)$ \\
\hline Outflow t-3 & & $0.104 * *(12.10)$ & $0.105^{* *}(11.01)$ \\
\hline Outflow t-4 & & $0.049 * *(5.57)$ & $0.047 * *(4.91)$ \\
\hline Outflow t-5 & & $0.036 * *(4.93)$ & $0.040 * *(4.83)$ \\
\hline Outflow t-6 & & $0.075 * *(8.36)$ & $0.079 * *(7.19)$ \\
\hline Outflow t-7 & & $0.008(1.08)$ & $0.000(0.02)$ \\
\hline Outflow t-8 & & $0.009(1.23)$ & $0.006(0.61)$ \\
\hline Outflow t-9 & & $0.013(1.65)$ & $0.016(1.76)$ \\
\hline Outflow t-10 & & $0.003(0.49)$ & $0.003(0.37)$ \\
\hline Outflow t-11 & & $0.008(1.31)$ & $0.011(1.43)$ \\
\hline Outflow t-12 & & $0.025 * *(3.72)$ & $0.020 *(2.37)$ \\
\hline Multiclass & $-0.002 * *(-5.94)$ & $-0.001 *(-2.15)$ & $-0.000(-1.54)$ \\
\hline InSize & $-0.000(-0.69)$ & $0.000(0.05)$ & $0.000(0.81)$ \\
\hline StdRet & $-3.395^{* *}(-16.51)$ & $-0.257 * *(-3.32)$ & $-0.350 * *(-3.89)$ \\
\hline ExpenseRatio & $-0.605 * *(-9.93)$ & $-0.142 * *(-4.47)$ & $-0.094 *(-2.63)$ \\
\hline EffectiveFrontLoad & $0.494^{* *}(32.34)$ & $0.069 * *(8.05)$ & $0.064 * *(6.46)$ \\
\hline EffectiveRedemptionFee & $-2.713 * *(-5.09)$ & $0.154(1.32)$ & $0.301(0.98)$ \\
\hline EffectiveCDSC & $0.631 * *(11.90)$ & $0.132 * *(5.84)$ & $0.126 * *(4.54)$ \\
\hline 12b-1 Fee & $-0.799 * *(-7.94)$ & $-0.092(-1.37)$ & $-0.106(-1.35)$ \\
\hline Adj-R2 & 0.1082 & 0.5824 & 0.6184 \\
\hline
\end{tabular}

This table presents results from Fama MacBeth regressions on our sample of 2,619 domestic equity mutual funds. There are 103,645 fund month observations from April 1997 to June 2003. The dependent variable is outflow, which is the amount of new money invested in the fund over a month, divided by the size of the fund at the beginning of the month. The independent variables are AbReturns, which are Fama-French four factor adjusted returns (where the adjustment is based on rolling betas estimates over the prior 36 months). Outflows are lagged values of the dependent variable. LnSize is the natural log of the fund's total net asset at the beginning of the month. StdRet is the standard deviation of the fund's abnormal monthly returns over the previous 12 months. ExpenseRatio is the expense ratio over the six month N-SAR reporting period. EffectiveFrontLoad is the money that the fund collected from the front-end load over the six month reporting period divided by the amount of new money flowing into 
the fund over the same six month reporting period. EffectiveRedemptionFee is the money generated from the fund's redemption fee over the six month reporting period divided by the amount of money withdrawn from the fund during the same six month reporting period. EffectiveCDSC is the money collected from the fund's contingent deferred sales charges over the six month reporting period divided by the amount of money withdrawn from the fund during the same six month reporting period. 12b-1 Fee is the money generated for the fund from 12-b1 fees over the six month reporting period divided by the size of the fund at the time of the N-SAR filing. ${ }^{* *}$ indicates significance at the $1 \%$ level. * indicates significance at the $5 \%$ level

In sum, our results suggest that contemporaneous and lagged monthly performance has an effect on current net flows and inflows. Additionally, regardless of the flows we examine, we find considerable persistence. These results are informative in that they show us that some investors respond to performance over periods shorter than a year, and suggest the importance of persistence in any examination of monthly fund flows.19

\subsection{Comparing the relative effects of performance and persistence}

The previous results suggest that lagged flows are more important than past performance in explaining cross-sectional flow variation. The previous analysis, however, does not paint a complete picture of the dynamics under investigation. Although the individual regression coefficients are informative in their own right, they only measure the static lead-lag relationships between flows and returns. By looking at them in isolation, one cannot answer questions like, what is the effect on flows after $x$ months of a shock in abnormal performance. Alternatively, if unexpectedly high inflows occur in a given month, what is their impact on future inflows after $x$ months? The presence of lagged dependent variables makes the model recursive. The lead-lag relation is, thus, not an immediate function of the individual regression coefficients. To investigate the dynamic relations we must look at the joint impact of past shocks and trace their effect over time. For these reasons, we now turn to impulse response analysis.

Our empirical regressions consist of lagged flows, abnormal returns and their lags, plus control variables, making them Auto-Regressive Distributed Lag (ARDL) models.20 We use the coefficients obtained from the Fama-MacBeth analysis and follow the procedure outlined in Greene (2002) to find the impulse response functions (or, dynamic multipliers), which trace the overall impact over time of a return shock on subsequent flows, and also the impact of a flow shock on future flows.

As is customary in dynamic multiplier analysis, we scale the inputs (return and flow shocks) by their respective standard deviations. The standard deviations are calculated by averaging the standard deviations across individual funds. As a result, the inputs are in standard deviation units. This makes the inputs comparable-without scaling, we would be comparing the effects of a $1 \%$ abnormal return with the effects of a $1 \%$ unexpected flow; However, these need not be equally representative of typical shock.

Figure 1 shows the cumulative response of flows to a one-standard-deviation shock in excess returns and, respectively, in flows. For example, in Fig. 1a, the total amount of net flows into an average fund twelve months after a one-standard-deviation return shock is equal to $3.4 \%$ of TNA at the time of the shock. After 40 months total net flows equal $5.3 \%$ of TNA. We are especially interested in a relative comparison of the effects associated with return shocks and flow shocks. It is clear from Fig. 1a that a one-standard-deviation shock in net flows produces a much larger net flow response than a one- 
standard-deviation shock in returns. After 12 and 40 months, the cumulative net flows following a onestandard-deviation flow shock are $13.1 \%$ and $17.0 \%$, respectively. In other words, a shock to net flows produces a net flow response that is about four times as large as the one induced by a comparable return shock. The analysis on inflows and outflows produces similar findings. For example, unexpectedly high inflows in a given month produce inflows after 12 months that are 6 times larger than the inflows produced by comparable performance shocks. Similarly, outflow shocks produce future outflows that are 25 times greater after 12 months than the outflows produced by a comparable abnormal return shock. Overall, the dynamic analysis reinforces our earlier inference that persistence plays a central role in the time series evolution of mutual fund flows.

\section{A}

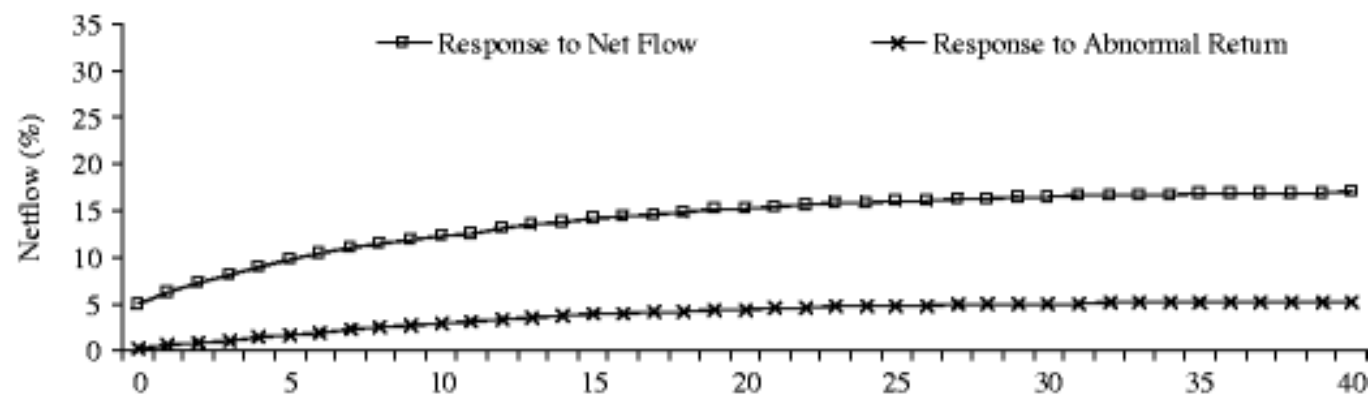

B

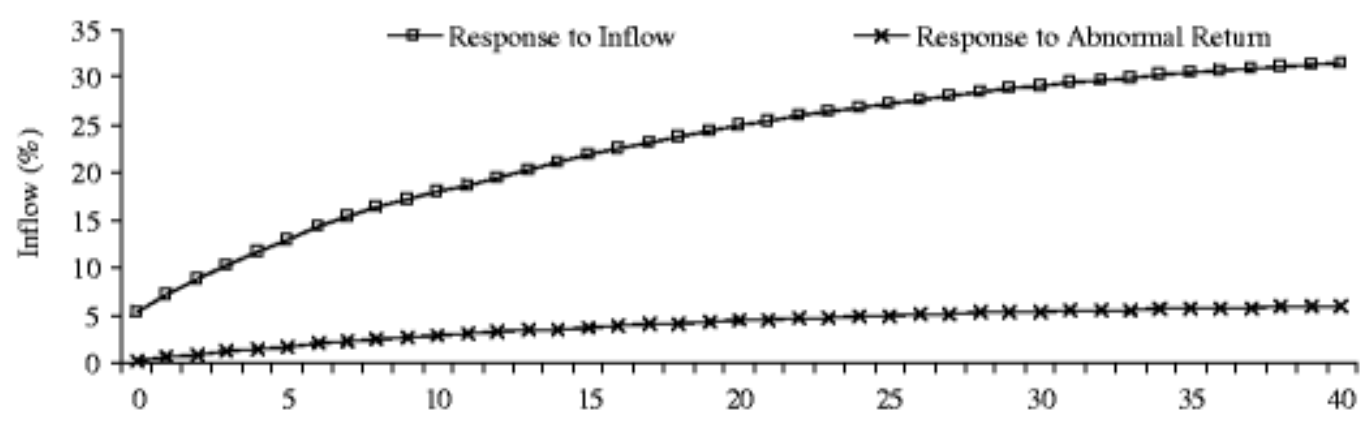

C

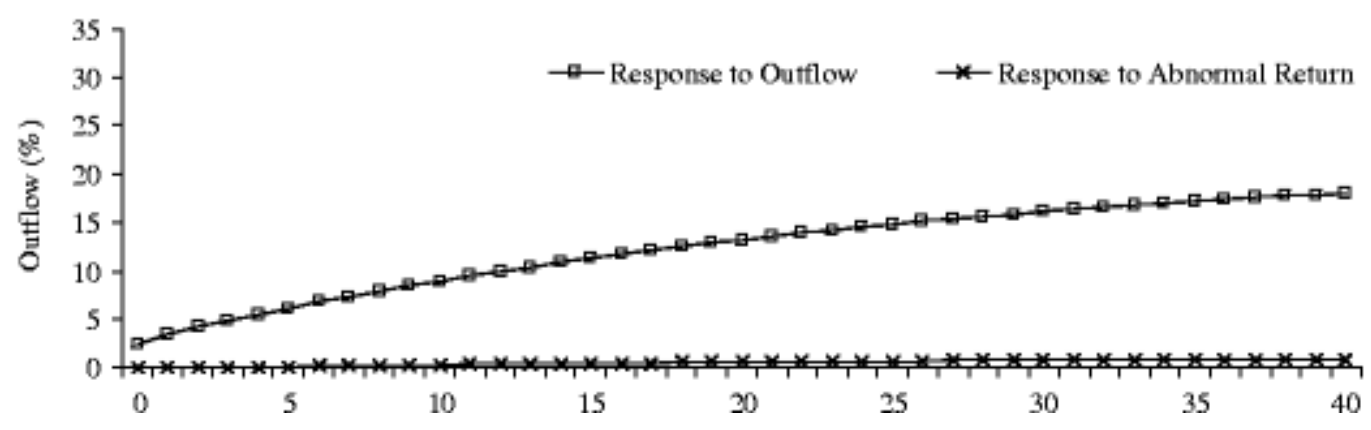

Fig. 1 Impact of performance vs. persistence for domestic equity fund flows. For domestic equity funds, we plot the cumulative impact on flow of a standard deviation shock in abnormal return and a standard deviation shock in flow. The horizontal axis represents lags in months and the vertical axis represents the flow response as a percentage of TNA. The response of flow to a unit change in abnormal return and flow were first calculated. A unit of flow and a unit of return may not be directly comparable due to 
possible differences in their distributions. Therefore, to make a homogeneous comparison we multiply the responses to return and flow shocks by their respective standard deviations. Panel a: Impact of performance vs. persistence on net flows to domestic equity funds. Panel b: Impact of performance vs. persistence on inflows to domestic equity funds. c: Impact of performance vs. persistence on outflows to domestic equity funds

\subsection{Comparing the relative persistence across flow types}

Figure 1a-c also allows for the comparison of the relative importance of persistence across flow types. To do so, we perform a similar impulse response analysis to that shown in Fig. 1, but we scale the flow responses by the average standard deviation of the respective flow-type. We do this because inflows and outflows are potentially drawn from different distributions. As we did earlier, we shock each flow type by its standard deviation. The resulting flows are, thus, expressed in the number of standard deviations of that flow type (e.g., a one-standard-deviation shock in inflows produces however many standard deviations of inflows in the future). The result is a shock and response that can be compared across flow types. Results of this analysis are shown in Fig. 2.

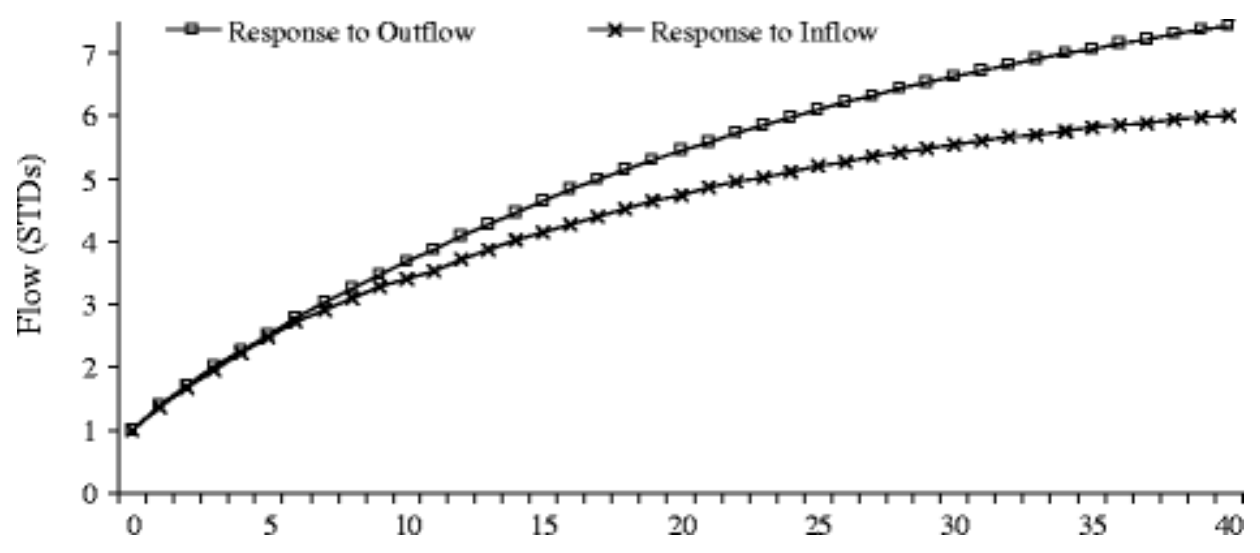

Fig. 2 Comparison of flow persistence across flow types for domestic equity funds. For domestic equity funds, we plot the impact of a standard deviation shock in flows on future flows, for each flow type. The horizontal axis represents lags in months and the vertical axis represents the flow response in standard deviations. The response of flow to a unit change in past flow was first computed. A unit of flow across different flow types may not be directly comparable due to possible differences in their distributions. Therefore, to make a homogeneous comparison, we scale the responses so that they are expressed in standard deviation of their respective flows

In Fig. 2, we see that outflows are more persistent than inflows. Focusing exclusively on net flows, as has been the case in much of the prior research, abstracts from a richer complexity in the underlying flow components. It appears that investors withdrawing money from mutual funds tend to do so in a somewhat more systematic fashion than investors putting money into mutual funds.

\section{Empirical results: comparisons across fund types}

Prior research has focused almost exclusively on domestic growth equity funds. We expand the analysis to include international equity funds and hybrid funds. Because different types of funds might have different investor clienteles and different risk-return profiles, we might expect a different response to fund performance across fund types. For each of these fund types, we re-estimate each of the final 
regression specifications from Tables 2, 3, and 4 and re-conduct the impulse response analysis as in Figs. 1 and 2. The results suggest that there are potentially meaningful differences across fund types with respect to how flows respond to performance and in the extent to which flows are persistent.

\subsection{The performance flow relation across fund types}

The analysis of net flows to domestic equity funds (Table 2 ), shows evidence that monthly performance affects net flows for up to twelve months. For international equity funds (Table 5, column 1 ) the effect appears more short-lived. Specifically, net flows are positively related to contemporaneous, one month and two month lagged returns. For the remaining lagged returns, only the fifth and the tenth months are statistically significant. A similar drop-off in the length of a performance effect holds for inflows as well. We also note that for international equity funds there is no relation between performance and outflows. This result is generally consistent with our findings on outflows for domestic equity funds.

Table 5 Determinants of flows by fund type

\begin{tabular}{|c|c|c|c|c|c|c|}
\hline & \multicolumn{3}{|c|}{ International Equity Funds } & \multicolumn{3}{|c|}{ Hybrid Funds } \\
\hline & Net Flow & Inflow & Outflow & Net Flow & Inflow & Outflow \\
\hline AbReturn $t$ & $\begin{array}{l}0.135^{* *} \\
(7.53)\end{array}$ & $\begin{array}{l}0.130 * * \\
(5.78)\end{array}$ & $\begin{array}{l}0.015 \\
(1.03)\end{array}$ & $\begin{array}{l}0.006 \\
(0.17)\end{array}$ & $\begin{array}{l}-0.046 \\
(-1.26)\end{array}$ & $\begin{array}{l}0.026 \\
(1.52)\end{array}$ \\
\hline AbReturn t-1 & $\begin{array}{l}0.100^{* *} \\
(4.90)\end{array}$ & $\begin{array}{l}0.091^{* *} \\
(3.93)\end{array}$ & $\begin{array}{l}-0.019 \\
(-1.09) \\
\end{array}$ & $\begin{array}{l}0.016 \\
(0.42) \\
\end{array}$ & $\begin{array}{l}0.031 \\
(0.83) \\
\end{array}$ & $\begin{array}{l}-0.005 \\
(-0.22) \\
\end{array}$ \\
\hline AbReturn t-2 & $\begin{array}{l}0.042^{*} \\
(2.18)\end{array}$ & $\begin{array}{l}-0.012 \\
(-0.59)\end{array}$ & $\begin{array}{l}0.004 \\
(0.21)\end{array}$ & $\begin{array}{l}0.096^{*} \\
(2.52)\end{array}$ & $\begin{array}{l}0.099 * * \\
(2.76)\end{array}$ & $\begin{array}{l}0.003 \\
(0.11)\end{array}$ \\
\hline AbReturn t-3 & $\begin{array}{l}0.012 \\
(0.61)\end{array}$ & $\begin{array}{l}-0.021 \\
(-0.79)\end{array}$ & $\begin{array}{l}0.017 \\
(0.86)\end{array}$ & $\begin{array}{l}0.010 \\
(0.23)\end{array}$ & $\begin{array}{l}0.020 \\
(0.45)\end{array}$ & $\begin{array}{l}0.013 \\
(0.59)\end{array}$ \\
\hline AbReturn t-4 & $\begin{array}{l}0.005 \\
(0.20)\end{array}$ & $\begin{array}{l}-0.031 \\
(-1.24)\end{array}$ & $\begin{array}{l}0.008 \\
(0.60)\end{array}$ & $\begin{array}{l}0.077^{*} \\
(2.12)\end{array}$ & $\begin{array}{l}0.060 \\
(1.51)\end{array}$ & $\begin{array}{l}0.012 \\
(0.53)\end{array}$ \\
\hline AbReturn t-5 & $\begin{array}{l}0.048^{*} \\
(2.05) \\
\end{array}$ & $\begin{array}{l}0.033 \\
(1.12) \\
\end{array}$ & $\begin{array}{l}-0.006 \\
(-0.39)\end{array}$ & $\begin{array}{l}0.025 \\
(0.66)\end{array}$ & $\begin{array}{l}-0.002 \\
(-0.04)\end{array}$ & $\begin{array}{l}0.026 \\
(1.39)\end{array}$ \\
\hline AbReturn t-6 & $\begin{array}{l}0.008 \\
(0.48)\end{array}$ & $\begin{array}{l}0.009 \\
(0.49)\end{array}$ & $\begin{array}{l}-0.018 \\
(-1.20)\end{array}$ & $\begin{array}{l}0.129 * * \\
(2.71)\end{array}$ & $\begin{array}{l}0.027 \\
(0.53)\end{array}$ & $\begin{array}{l}0.055^{*} \\
(2.57)\end{array}$ \\
\hline AbReturn t-7 & $\begin{array}{l}-0.008 \\
(-0.52)\end{array}$ & $\begin{array}{l}-0.024 \\
(-1.14)\end{array}$ & $\begin{array}{l}-0.011 \\
(-0.59)\end{array}$ & $\begin{array}{l}0.082^{*} \\
(2.29)\end{array}$ & $\begin{array}{l}0.066 \\
(1.30)\end{array}$ & $\begin{array}{l}-0.010 \\
(-0.48)\end{array}$ \\
\hline AbReturn t-8 & $\begin{array}{l}0.026 \\
(1.09) \\
\end{array}$ & $\begin{array}{l}0.009 \\
(0.37) \\
\end{array}$ & $\begin{array}{l}0.017 \\
(0.98) \\
\end{array}$ & $\begin{array}{l}0.082 \\
(1.69)\end{array}$ & $\begin{array}{l}0.078 \\
(1.78) \\
\end{array}$ & $\begin{array}{l}0.054^{*} \\
(2.56)\end{array}$ \\
\hline AbReturn t-9 & $\begin{array}{l}0.019 \\
(0.80)\end{array}$ & $\begin{array}{l}-0.018 \\
(-0.64)\end{array}$ & $\begin{array}{l}0.016 \\
(0.90)\end{array}$ & $\begin{array}{l}0.068 \\
(1.51)\end{array}$ & $\begin{array}{l}-0.011 \\
(-0.21)\end{array}$ & $\begin{array}{l}0.037 \\
(1.45)\end{array}$ \\
\hline AbReturn t-10 & $\begin{array}{l}0.076^{* *} \\
(3.42)\end{array}$ & $\begin{array}{l}0.058^{*} \\
(2.33)\end{array}$ & $\begin{array}{l}-0.003 \\
(-0.14)\end{array}$ & $\begin{array}{l}0.081^{*} \\
(2.01)\end{array}$ & $\begin{array}{l}0.060 \\
(1.36)\end{array}$ & $\begin{array}{l}0.009 \\
(0.37)\end{array}$ \\
\hline AbReturn t-11 & $\begin{array}{l}0.004 \\
(0.16)\end{array}$ & $\begin{array}{l}0.015 \\
(0.58)\end{array}$ & $\begin{array}{l}-0.020 \\
(-1.05)\end{array}$ & $\begin{array}{l}0.026 \\
(0.56)\end{array}$ & $\begin{array}{l}0.018 \\
(0.40)\end{array}$ & $\begin{array}{l}-0.009 \\
(-0.39)\end{array}$ \\
\hline AbReturn t-12 & $\begin{array}{l}0.018 \\
(0.88)\end{array}$ & $\begin{array}{l}-0.012 \\
(-0.59)\end{array}$ & $\begin{array}{l}-0.006 \\
(-0.34)\end{array}$ & $\begin{array}{l}0.112^{* *} \\
(2.82)\end{array}$ & $\begin{array}{l}0.092^{*} \\
(2.45)\end{array}$ & $\begin{array}{l}0.018 \\
(0.81)\end{array}$ \\
\hline Flow t-1 & $\begin{array}{l}0.192^{* *} \\
(9.15)\end{array}$ & $\begin{array}{l}0.520 * * \\
(18.76)\end{array}$ & $\begin{array}{l}0.555 * * \\
(23.53)\end{array}$ & $\begin{array}{l}0.200 * * \\
(7.87)\end{array}$ & $\begin{array}{l}0.278^{* *} \\
(9.24)\end{array}$ & $\begin{array}{l}0.234^{* *} \\
(9.27)\end{array}$ \\
\hline Flow t-2 & $\begin{array}{l}0.119 * * \\
(7.32)\end{array}$ & $\begin{array}{l}0.159 * * \\
(6.77)\end{array}$ & $\begin{array}{l}0.173^{* *} \\
(8.28)\end{array}$ & $\begin{array}{l}0.134^{* *} \\
(5.56)\end{array}$ & $\begin{array}{l}0.182^{* *} \\
(6.87)\end{array}$ & $\begin{array}{l}0.160 * * \\
(6.82)\end{array}$ \\
\hline
\end{tabular}




\begin{tabular}{|c|c|c|c|c|c|c|}
\hline Flow t-3 & $\begin{array}{l}0.102^{* *} \\
(6.86)\end{array}$ & $\begin{array}{l}0.091^{* *} \\
(4.83)\end{array}$ & $\begin{array}{l}0.056^{* *} \\
(3.35)\end{array}$ & $\begin{array}{l}0.065^{* *} \\
(3.09)\end{array}$ & $\begin{array}{l}0.086 * * \\
(3.60)\end{array}$ & $\begin{array}{l}0.116^{* *} \\
(5.18)\end{array}$ \\
\hline Flow t-4 & $\begin{array}{l}0.059 * * \\
(3.45)\end{array}$ & $\begin{array}{l}0.035 \\
(1.70)\end{array}$ & $\begin{array}{l}0.035 \\
(1.63)\end{array}$ & $\begin{array}{l}0.068^{* *} \\
(3.62)\end{array}$ & $\begin{array}{l}0.060 * * \\
(3.12)\end{array}$ & $\begin{array}{l}0.073^{* *} \\
(2.91)\end{array}$ \\
\hline Flow t-5 & $\begin{array}{l}0.045^{* *} \\
(2.92)\end{array}$ & $\begin{array}{l}0.052^{* *} \\
(2.98)\end{array}$ & $\begin{array}{l}0.028 \\
(1.53)\end{array}$ & $\begin{array}{l}0.087^{* *} \\
(3.94)\end{array}$ & $\begin{array}{l}0.045 \\
(1.96)\end{array}$ & $\begin{array}{l}0.056^{* *} \\
(2.81)\end{array}$ \\
\hline Flow t-6 & $\begin{array}{l}0.041^{* *} \\
(2.97)\end{array}$ & $\begin{array}{l}0.029 \\
(1.85)\end{array}$ & $\begin{array}{l}0.049 * \\
(2.64)\end{array}$ & $\begin{array}{l}0.021 \\
(0.99)\end{array}$ & $\begin{array}{l}0.044^{*} \\
(2.03)\end{array}$ & $\begin{array}{l}0.083^{* *} \\
(3.53)\end{array}$ \\
\hline Flow t-7 & $\begin{array}{l}0.016 \\
(1.08)\end{array}$ & $\begin{array}{l}0.009 \\
(0.48)\end{array}$ & $\begin{array}{l}-0.009 \\
(-0.47)\end{array}$ & $\begin{array}{l}-0.009 \\
(-0.37)\end{array}$ & $\begin{array}{l}-0.025 \\
(-1.21)\end{array}$ & $\begin{array}{l}0.005 \\
(0.23)\end{array}$ \\
\hline Flow $\mathrm{t}-8$ & $\begin{array}{l}0.018 \\
(1.17)\end{array}$ & $\begin{array}{l}-0.017 \\
(-1.08)\end{array}$ & $\begin{array}{l}0.009 \\
(0.46)\end{array}$ & $\begin{array}{l}0.007 \\
(0.32)\end{array}$ & $\begin{array}{l}0.026 \\
(0.96)\end{array}$ & $\begin{array}{l}0.073^{* *} \\
(3.07)\end{array}$ \\
\hline Flow t-9 & $\begin{array}{l}-0.009 \\
(-0.76)\end{array}$ & $\begin{array}{l}0.014 \\
(0.83)\end{array}$ & $\begin{array}{l}0.002 \\
(0.10)\end{array}$ & $\begin{array}{l}0.029 \\
(1.55)\end{array}$ & $\begin{array}{l}0.021 \\
(1.14)\end{array}$ & $\begin{array}{l}0.033 \\
(1.44)\end{array}$ \\
\hline Flow t-10 & $\begin{array}{l}0.005 \\
(0.41)\end{array}$ & $\begin{array}{l}-0.008 \\
(-0.69)\end{array}$ & $\begin{array}{l}0.031 \\
(1.84)\end{array}$ & $\begin{array}{l}-0.007 \\
(-0.36)\end{array}$ & $\begin{array}{l}-0.020 \\
(-0.94)\end{array}$ & $\begin{array}{l}0.036 \\
(1.67)\end{array}$ \\
\hline Flow t-11 & $\begin{array}{l}0.002 \\
(0.16)\end{array}$ & $\begin{array}{l}0.015 \\
(0.67)\end{array}$ & $\begin{array}{l}-0.019 \\
(-1.12)\end{array}$ & $\begin{array}{l}0.004 \\
(0.25)\end{array}$ & $\begin{array}{l}0.019 \\
(0.94)\end{array}$ & $\begin{array}{l}-0.001 \\
(-0.03)\end{array}$ \\
\hline Flow t-12 & $\begin{array}{l}0.073^{* *} \\
(5.16)\end{array}$ & $\begin{array}{l}0.037^{*} \\
(2.17)\end{array}$ & $\begin{array}{l}0.052^{* *} \\
(3.37)\end{array}$ & $\begin{array}{l}0.074^{* *} \\
(4.80)\end{array}$ & $\begin{array}{l}0.111^{* *} \\
(5.68)\end{array}$ & $\begin{array}{l}0.036^{*} \\
(2.29)\end{array}$ \\
\hline Multiclass & $\begin{array}{l}0.001 \\
(1.29)\end{array}$ & $\begin{array}{l}0.001 \\
(1.20)\end{array}$ & $\begin{array}{l}-0.001 \\
(-1.01)\end{array}$ & $\begin{array}{l}0.001 \\
(0.66)\end{array}$ & $\begin{array}{l}0.000 \\
(0.48)\end{array}$ & $\begin{array}{l}-0.000 \\
(-0.05)\end{array}$ \\
\hline InSize & $\begin{array}{l}-0.001^{* *} \\
(-4.55)\end{array}$ & $\begin{array}{l}-0.001^{* *} \\
(-4.38)\end{array}$ & $\begin{array}{l}0.000 \\
(1.87)\end{array}$ & $\begin{array}{l}-0.001^{* *} \\
(-4.00)\end{array}$ & $\begin{array}{l}-0.001^{* *} \\
(-3.18)\end{array}$ & $\begin{array}{l}0.000- \\
(0.66)\end{array}$ \\
\hline StdRet & $\begin{array}{l}0.290 \\
(-0.54)\end{array}$ & $\begin{array}{l}0.325 \\
(-0.68)\end{array}$ & $\begin{array}{l}0.047 \\
(-0.14)\end{array}$ & $\begin{array}{l}1.132 \\
(0.89)\end{array}$ & $\begin{array}{l}1.581 \\
(1.08)\end{array}$ & $\begin{array}{l}-1.448 * * \\
(-2.89)\end{array}$ \\
\hline ExpenseRatio & $\begin{array}{l}-0.384^{* *} \\
(-3.75)\end{array}$ & $\begin{array}{l}0.009 \\
(0.08)\end{array}$ & $\begin{array}{l}-0.185^{*} \\
(-2.16)\end{array}$ & $\begin{array}{l}-0.592^{* *} \\
(-4.14)\end{array}$ & $\begin{array}{l}-0.319 * * \\
(-2.75)\end{array}$ & $\begin{array}{l}-0.053 \\
(-0.88)\end{array}$ \\
\hline EffectiveFrontLoad & $\begin{array}{l}-0.092 * \\
(-2.02)\end{array}$ & $\begin{array}{l}-0.249 * * \\
(-5.72)\end{array}$ & $\begin{array}{l}0.160 * * \\
(3.73)\end{array}$ & $\begin{array}{l}0.036 \\
(0.89)\end{array}$ & $\begin{array}{l}-0.102 * * \\
(-3.02)\end{array}$ & $\begin{array}{l}0.079 * * \\
(3.38)\end{array}$ \\
\hline EffectiveRedemptionFee & $\begin{array}{l}0.610^{* *} \\
(2.98)\end{array}$ & $\begin{array}{l}-0.114 \\
(-0.45)\end{array}$ & $\begin{array}{l}-0.426^{*} \\
(-2.27)\end{array}$ & $\begin{array}{l}0.356 \\
(0.76)\end{array}$ & $\begin{array}{l}-0.099 \\
(-0.32)\end{array}$ & $\begin{array}{l}0.069 \\
(0.79)\end{array}$ \\
\hline EffectiveCDSC & $\begin{array}{l}-0.211 \\
(-1.16)\end{array}$ & $\begin{array}{l}-0.632^{* *} \\
(-3.53)\end{array}$ & $\begin{array}{l}0.257 \\
(1.32)\end{array}$ & $\begin{array}{l}-0.043 \\
(-0.39)\end{array}$ & $\begin{array}{l}-0.096 \\
(-1.02)\end{array}$ & $\begin{array}{l}0.028 \\
(0.63)\end{array}$ \\
\hline $12 b-1$ Fee & $\begin{array}{l}-0.153 \\
(-0.60)\end{array}$ & $\begin{array}{l}0.206 \\
(0.79)\end{array}$ & $\begin{array}{l}0.047 \\
(0.20)\end{array}$ & $\begin{array}{l}0.363 \\
(1.17)\end{array}$ & $\begin{array}{l}0.005 \\
(0.02)\end{array}$ & $\begin{array}{l}0.098 \\
(0.86)\end{array}$ \\
\hline Adj-R2 & 0.3680 & 0.6686 & 0.7451 & 0.4271 & 0.5330 & 0.5123 \\
\hline
\end{tabular}

This table presents results from Fama MacBeth regressions of our sample of 867 international equity mutual funds and 350 hybrid funds. There are 28,547 international equity fund month observations, and 14,925 hybrid fund month observations from April 1997 to June 2003. Column 1 and 4 presents our analysis of net flows, Column 2 and 5 presents our analysis of inflows, Column 3 and 6 presents our analysis of outflows. AbReturns, are the lagged abnormal returns. International equity fund's raw returns are adjusted using the Morgan Stanley international index, and the broad trade weighted exchange index, the individual fund's loadings are rolling estimates over the prior 36 months. The hybrid fund's returns are adjusted using both bond and equity market factors. Namely, we include factors accounting for the bond market's term, credit, and liquidity premiums; we also include the equity market return, and the equity market volatility index, lastly we include the factors measuring exchange 
rate and the Chen, Ferson, and Peters (2008) mortgage spread. Flows are lagged values of the dependent variable. LnSize is the natural log of the fund's total net asset at the beginning of the month. StdRet is the standard deviation of the fund's abnormal monthly returns over the previous 12 months. ExpenseRatio is the expense ratio over the six month N-SAR reporting period. EffectiveFrontLoad is the money that the fund collected from the front-end load over the six month reporting period divided by the amount of new money flowing into the fund over the same six month reporting period. EffectiveRedemptionFee is the money generated from the fund's redemption fee over the six month reporting period divided by the amount of money withdrawn from the fund during the same six month reporting period. EffectiveCDSC is the money collected from the fund's contingent deferred sales charges over the six month reporting period divided by the amount of money withdrawn from the fund during the same six month reporting period. $12 b-1$ Fee is the money generated for the fund from 12-b1 fees over the six month reporting period divided by the size of the fund at the time of the N-SAR filing. ** indicates significance at the $1 \%$ level. * indicates significance at the $5 \%$ level

Results for hybrid funds are somewhat mixed: the importance of performance is less clear. Performance in a given month does not appear to affect contemporaneous net flows, or even flows in the next month, but it does appear to affect flows two months later. Returns at the fourth, sixth, seventh, tenth, and twelfth lags are also statistically significant. Oddly, though, there is little consistent evidence of performance affecting inflows or outflows.

To make a more formal comparison of differences in flow characteristics across fund types we repeat our earlier impulse-response analysis, which allows us to gain a better understanding of how performance shocks map into future flows. Figure 3 shows the response of inflows to a one-standarddeviation abnormal performance.21 As it was the case in Fig. 2, the responses are in terms of the number of standard deviations of that fund type's inflows. We do this because the distributions of inflows are potentially different across fund types. We see in Fig. 3 that hybrid fund inflows are systematically less responsive to performance than either domestic equity or international funds: the additional inflows induced by a comparable abnormal performance are barely half for hybrid funds than what they are for the other two fund types. Figure 3 also shows that the performance flow relation does not differ substantially between domestic and international equity funds, except at very long lags (30 to 40 months).

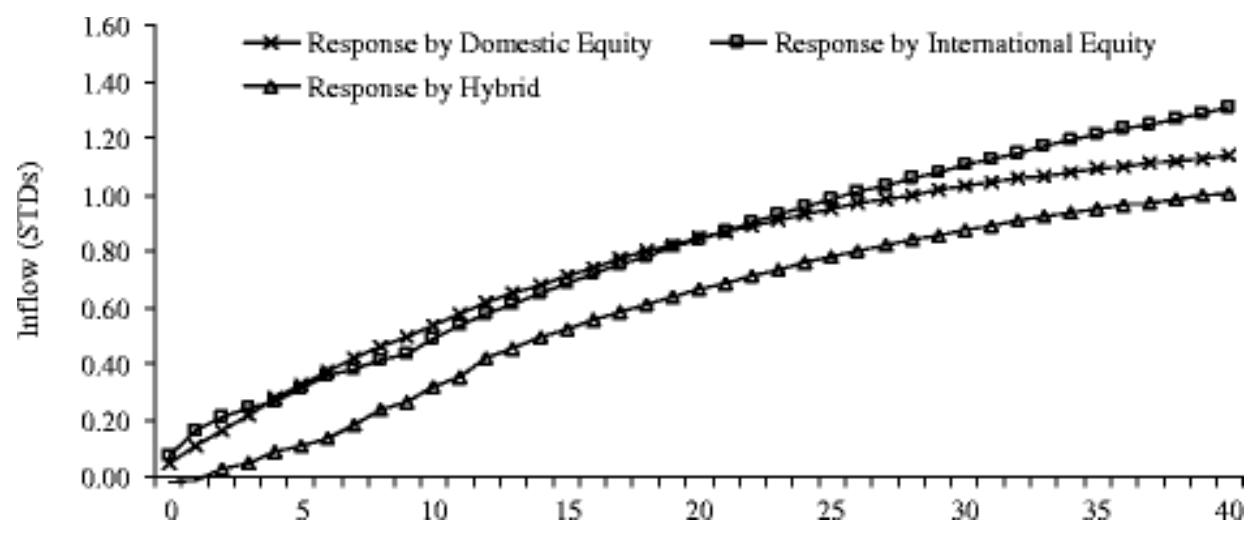

Fig. 3 Comparison of impact of performance on inflow across fund types. For each fund type, we plot the cumulative impact on inflow of a standard deviation shock in abnormal return. The horizontal axis represents lags in months and the vertical axis represents the inflow response in standard deviations. A 
unit of abnormal return (input) may not be directly comparable across different fund types, due to possible differences in their distributions. In addition, a unit of inflow (output) across different fund types may also not be directly comparable. Therefore, to make a homogeneous comparison, we first multiply the responses by the standard deviation of returns and then scale them by the standard deviation of the respective inflow

\subsection{Flow persistence across fund types}

Persistence appears to be present in all flow characterizations. From Table 5, however, there appears to be a considerable difference in the persistence of flow components for international equity funds relative to domestic equity funds. For example, the coefficients on one-month lagged inflows and outflows for international equity funds are 0.520 and 0.555 , respectively. The comparable values for domestic equity funds are 0.371 and 0.386 . These results would seem to suggest that persistence is a more important determinant of inflows and outflows in international equity funds than it is for domestic equity funds.

As we did earlier, we assess the combined impact of past flows on future flows through impulse response analysis. Figure 4 shows the response of inflows and outflows to a one-standard-deviation shock in each of the flow types. In Fig. 4a, we see that inflows are the most persistent for international equity funds, then for domestic equity funds, and then for hybrid funds. The exact same relation holds for fund outflows -international equity outflows are the most persistent followed by domestic equity followed by hybrid. In terms of economic magnitudes (i.e., percentages of TNA), the large differences displayed in Fig. 4 appear to be non-trivial.

A

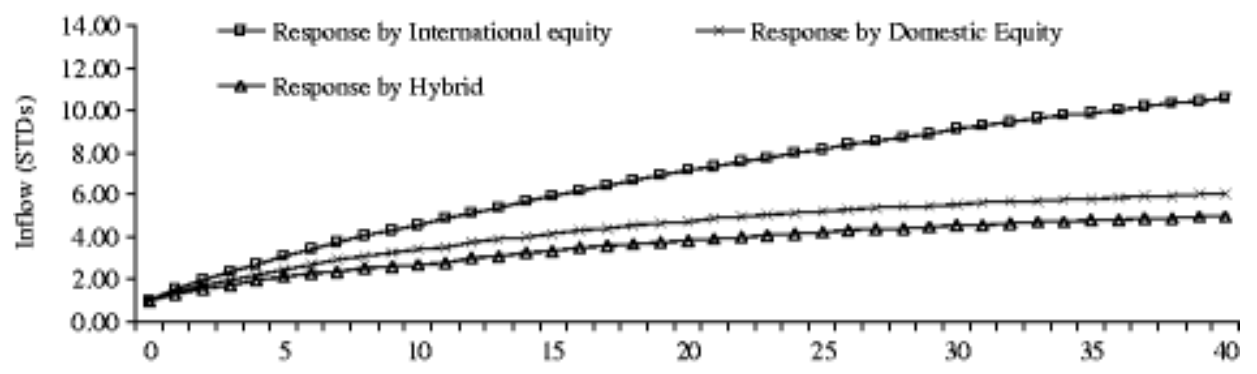

B

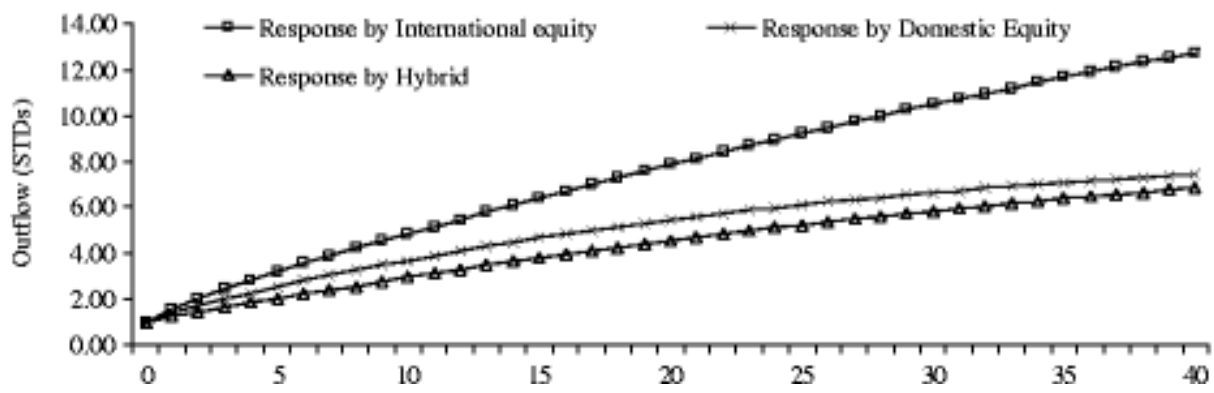

Fig. 4 Comparison of flow persistence within each flow type across funds. For each fund type, we plot the impact of a standard deviation shock in flows on future flows. The horizontal axis represents lags in months and the vertical axis represents the flow response in standard deviations. The response of flows to a unit change in past flows was first computed. A unit of flow across different fund types may not be 
directly comparable. Therefore, to make a homogeneous comparison, we scale the responses so that they are expressed in standard deviation of their respective flows. Panel a: Comparison of inflow persistence across different fund types. Panel b: Comparison of outflow persistence across different fund types

In sum, the results in this section suggest that there is meaningful variation in the determinants of mutual fund flows across fund types and that prior research focusing almost exclusively on domestic equity funds paints a less-than-complete picture. Our results suggest that performance is more important to future flows for domestic equity funds and for international equity funds than it is for hybrid funds. Persistence in monthly flows, however characterized, appears to be a phenomenon common to each type of fund, but it varies in intensity across fund and flow types.

\section{Robustness issues}

All our empirical analysis thus far relies on the widely used Fama-MacBeth approach. The purpose of this section is to show that this methodology is appropriate. In addition, we show that all our baseline results are robust to several changes in the estimation and inference procedure. 22

As an alternative to the Fama-MacBeth method, one could attempt to exploit more directly the panel features of the data. In particular, if there were unobservable (or, omitted) fund characteristics affecting investments flows, a panel regression with, say, fixed effects could be more appropriate. To accommodate this possibility, we run panel estimation with fund fixed effects for all our flow regressions. We use a standard Within Estimator and correct the standard errors for general crosscorrelation as well as for cross-sectional heteroskedasticity across fund residuals. Alternatively, we correct for general serial correlation in the residuals of each fund.23 We then recalculate the Impulse Response function using the fixed effects estimates. First, the pattern of significance (or, lack of it) reported in Tables 2 through 5 is essentially unaltered. Second, although we observe some differences in individual coefficients, the much more informative impulse responses are extremely similar in shape and level to those reported in Figs. 1 through 4. Consequently, both the ordinal and the cardinal differences presented in the previous sections appear to be very robust to the inclusion of fund fixed effects.

Complications arise in panel estimation when lagged dependent variables are included among the regressors.24 Specifically, if the left-hand side variables are not strictly exogenous (as it is the case whenever lagged values of the dependent variable are included among the regressors), the standard fixed-effect estimator is inconsistent. In principle, one would then rely on dynamic panel methods, which typically employ Generalized Method of Moments (GMM) techniques.25 Two considerations, however, make them less appealing for our framework. First, an attempt to achieve the efficiency gains induced by GMM would likely be infeasible because of the enormous number of moment conditions the estimation would require. In fact, in such a situation GMM may well generate downward biased estimates.26 Second, as Wooldridge (Ch. 11) shows, the inconsistency of the fixed effect estimators is of order $1 / T$, where $T$ denotes the time-series sample size. While in most panel analyses (typically based on annual data) this is a serious concern, in our dataset $(T=75)$ the distortions are likely to be quite small.

Another set of issues pertains to the calculation of the standard errors. At the general level, the problem is that the disturbances may be correlated both across funds for the same time period and across time for any given fund. The corrections we discussed above for the fixed effect estimates are robust either 
to one or to the other type of residual dependence. The Fama-MacBeth approach is mainly designed to control for contemporaneous cross-correlations.

In order to establish what type of adjustment is more relevant for our applications, we largely follow Petersen's (2006) suggestions. As a first step, we calculate White standard errors, by running a pooled OLS regression on our empirical specifications. White standard errors are not robust to within cluster dependence. As a next step, we estimate Rogers' standard errors by clustering first across funds and then across time. Clustering across time yields standard errors that are approximately three times larger in magnitude relative to White standard errors, whereas clustering by funds yields standard errors that are not far off in magnitude compared to White's. 27

Given the above results, we conclude that the contemporaneous dependence across fund residuals is much more important than the possible serial correlation for individual fund residuals across time. This is yet another confirmation that the Fama-MacBeth approach we adopt is very likely to produce the correct inferences.

A final issue we address is the potential bias in the standard errors induced by serial correlation in the coefficient estimates obtained from each cross-sectional regression.28 Following, among others, Pontiff (1996) we run time-series regressions for each of the coefficient estimates on a constant and model the error as an autoregressive process. To make sure that we remove the persistence in the coefficient estimates, we model the errors as a sixth-order AR process. The standard error obtained for the intercept in the above regression is the corrected standard error. None of the coefficients obtained for the AR components were significant and t-statistics obtained by using the corrected standard errors did not drop significantly, suggesting that there was not enough persistence in the estimates to distort the standard errors we report in our baseline analysis.

In sum, after a battery of checks on the estimation methodology and/or on the inferential approach, we conclude that all our main findings based on the simple Fama-MacBeth method are remarkably robust.

\section{Discussion and additional analysis}

In the preceding analysis, we document several new empirical regularities associated with monthly mutual fund flows. In this section, we examine how our results provide for a better understanding on investor behavior, and how this behavior may influence advisor behavior.

\subsection{Mutual fund flows are persistent}

Persistence is a lightly considered aspect of mutual fund flows. Del Guercio and Tkac (2002) consider persistence in annual net mutual fund flows, but persistence in monthly net and gross mutual fund flows has been ignored to date. More importantly, previous studies do not investigate the impact of flow persistence on the performance flow relation. Thus, our results represent new evidence on this important characteristic of mutual fund flows. A critical aspect of our analysis is that we demonstrate the large magnitude of the effects associated with persistence in fund flows. Given the first-order importance of persistence in explaining future flows (demonstrated in Section 3.3), we believe this new evidence is important to our understanding of investor behavior.

We consider two possible interpretations of our results with respect to what they indicate about investor behavior. The first interpretation of flow persistence, which we refer to as the "streaminess" 
interpretation, is that investors react to performance by moving streams of money, rather than lump sums. The second interpretation, which we refer to as the differential learning/reacting rate interpretation, is that investors either learn about performance at different rates, or they learn at the same rate, but react at different time intervals to the same piece of information. Investors, then, move a lump sum, but because they either learn/react to new performance at different rates, their movement produces persistent fund-level flows.

Given that our data is at the level of the fund and not the individual investor, it is impossible for us to distinguish between these two possibilities. We do think, however, that our results point us in a particular direction. Consider the results on fund outflows. We find that outflows demonstrate relatively little sensitivity to fund performance, but are systematically more persistent than fund inflows (see Fig. 2). It seems reasonable to suggest that the persistence demonstrated by fund outflows cannot be a byproduct of differential learning/reacting rates because outflows are relatively insensitive to performance in the first place. To the extent we can generalize this intuition; the results on outflows suggest that persistence in fund flows is more likely a product of investors moving streams of money in response to performance than differential learning/reacting rates.

Another possibility is that persistence in fund flows is driven by retirement saving. Cohen and Schmidt (2009) point out the importance of retirement investing through Defined Contribution Plans and Individual Retirement Accounts as a source of flows in the mutual fund industry. The percentage of mutual fund assets held in those types of accounts hovered around $35 \%-36 \%$ during our sample period (Investment Company Institute (2009)). Because these types of accounts tend to limit investor choice and typically involve investors making regular purchases or withdrawals, their presence could induce at least a portion of the persistence that we observe in fund flows.29

Ideally, we would be able to compare fund flows from retirement and non-retirement sources. Flow data by share class would help in that regard. Unfortunately, our flow data is at the level of the fund, not the level of the share class. We do two things, though, to get at the relevance of retirement investing to the persistence of flows. First, because funds offered through DC plans and IRAs tend to have multiple share classes, we eliminate all funds with multiple share classes from our sample and repeat our analysis. In every case flows remain persistence. Second, we interact our multi-class indicator variable with our return and prior flow explanatory variables and repeat our analysis. We find flow responses similar to our earlier results and no evidence of that the flows to funds with multiple share classes are more or less persistent than flows to funds with only a single share class. Overall, we take this evidence that the "streaminess" in mutual fund flows is not being driven exclusively by retirement savings.

\subsection{Investors respond differently to performance across fund types}

Prior research has had little to say about potential differences in the performance flow relation across fund types, they typically limit the sample to a single mutual fund type. Our results suggest that investors evaluate and respond differently to fund performance across fund types, which introduce several interesting possibilities.

Mutual fund investors may be heterogeneous with different types being unequally distributed across mutual fund types. This somewhat basic consideration is absent from the prior literature and thus suggests the importance of the result. It is also possible that investors face different relative costs in evaluating and responding to performance across different types of funds. For example, we find that 
investors in hybrid funds respond less to performance than investors in domestic and international equity funds. Perhaps it is the case that hybrid fund investors face higher costs in evaluating and responding to performance than investors in domestic and international equity funds.

Our result also introduces an interesting possibility with respect to differences in investors' beliefs about managerial ability. Berk and Green (2004) model a world in which mutual fund advisors are endowed with ability. Investors rationally respond to good performance because of what it reveals about manager ability, but diseconomies of scale resulting from net fund inflows eliminate an advisor's ability to generate persistent abnormal returns. Our results add a cross-sectional (i.e., across fund types) flavor to Berk and Green's analysis. Interpreting our results in their framework would suggest that investors believe there is greater managerial ability in some fund types than in others. Specifically, our results are consistent with investors believing that domestic and international equity fund managers have greater ability than hybrid fund advisors. 30 Investors do not respond (as much) to hybrid fund performance, because they do not believe that it is indicative of actual advisor ability.

\subsection{Flow persistence is different among fund types}

As was the case with differences in the performance flow relation among mutual fund types, we find differences in the persistence of flows across mutual fund types. In particular, we find that gross flows for international funds tend to be more persistent than for domestic equity funds which are, in turn, more persistent than gross flows for hybrid funds. In addition, as was the case with the performance flow relation across fund types, these differences in persistence can be interpreted as differences in investor behavior across the different types of funds. Prior research has not considered differences in this dimension of investor behavior. These differences can be interpreted as suggesting that mutual fund investors are heterogeneous or, alternatively, that they face different relative costs which then drive differences in their trading behavior. We leave it to future research to distinguish between these two possibilities.

\subsection{Investors respond to performance over shorter windows}

We find that at least some mutual fund investors appear to evaluate and respond to mutual fund performance at the monthly time interval. Prior large-sample studies document investor reaction to annual performance, but have largely ignored investor responses to shorter-term performance. Thus, our result is important because it offers the first large-sample evidence that investors evaluate and respond to fund performance over much shorter windows than previously documented.

Our results are also potentially important to understanding an ongoing debate over the extent to which investors' reactions to mutual fund performance create incentives for fund advisors to manipulate risk within a year. The basic premise of this "tournament" argument is that investors evaluate and respond to annual mutual fund performance and that investor reactions to fund performance are asymmetric (consistent with prior research). Because investors respond to annual fund performance, advisors have an incentive to manipulate fund risk in the later part of a year based on performance in the earlier part of the year. Funds that have done well during the first part of a year will reduce risk to "lock-in" good annual performance while funds that have done poorly during the first part of a year will increase fund risk in the hopes of generating a high return. Early research by Brown et al. (1996) and Chevalier and Ellison (1997) finds evidence consistent with this intra-year risk-shifting incentive. Subsequent research, however, has found somewhat more mixed results. 31 
Our results suggest that at least some portion of mutual fund investors are evaluating and responding to mutual fund performance over a much shorter window than a year. Our findings that some portion of investors respond to performance over periods shorter than a year, would seem to weaken the incentive for advisors to manipulate risk in response to beginning of year performance, as described in Brown et al. (1996). Of course, our finding that at least some investors evaluate and respond to fund monthly performance also introduces the possibility of monthly tournaments, which, in turn, introduces the possibility of advisor incentives to shift risk within a month.

\subsection{Flow persistence is different between flow types}

We document that there are differences in the persistence of the different flow types and in particular, that outflows are more persistent than inflows. What does that result suggest about investor behavior? Continuing the discussion from Section 6.1, if one is willing to link persistence to "streaminess" in fund flows it suggests that both investors who are investing in funds and investors who are withdrawing from funds do so in a systematic fashion, but investors who are withdrawing from funds do so in a more systematic fashion. This interpretation suggests heterogeneity between investors who are selling fund shares and investors who are purchasing fund shares. As noted earlier, a potential heterogeneity between fund investors has been hinted at in the prior literature as an explanation for the asymmetric relation between performance and net flows documented by Sirri and Tufano (1998). There, the assertion is that investors who could potentially sell fund shares are less sensitive to fund performance than are investors who could purchase fund shares. Our results document another potentially important dimension of investor heterogeneity-investors differ in the persistence of their flows.

\section{Conclusion}

We provide new evidence on investor behavior by examining the dynamics of gross flows in the mutual fund industry. Using a large sample of monthly observations on net flows, inflows, and outflows, we uncover several previously undocumented features of investor behavior. We also discuss their potential implications for the incentives faced by fund advisors. In doing so, we make three primary contributions to the literature. First, we document the central role of persistence in mutual fund flows (whether they are net flows, inflows, or outflows). We note that failure to account for the persistence in mutual fund flows affects our inferences with respect to the relation between performance and subsequent flows. Second, we find economically relevant differences in flow characteristics and in the performance flow relation across different types of funds. Third, our results suggest that at least some portion of the investors' population evaluates and responds to performance over windows significantly shorter than the year.

\section{Footnotes}

1. Patel et al. (1994), Fant and O'Neal (2000), and Del Guercio and Tkac (2002) find autocorrelation in annual net flows. Johnson (2007) examines autocorrelation in daily flows. Warther (1995) examines the autocorrelation in annual aggregate net cash flows. However, none of these studies assesses the impact of flow persistence on the performance flow relation.

2. Ivkovich and Weisbenner (2006) explicitly exclude multiple transactions (by a given investor) from their sample.

3. A hybrid fund is a fund that invests in a mix of equity and debt. 
4. Del Guercio and Tkac (2007) examine the effect of changes in a fund's Morningstar ranking to its monthly fund flows, and find that a decline (increase) in fund's ranking is followed by a decline (increase) in flows the following months. Johnson (2007) provides some evidence on monthly performance flow relation, but Johnson's sample is drawn from about ten funds within a single family, making it unclear if the results would hold generally. Johnson (2007) notes that "Only future research can definitively address this concern". Warther (1995) analyzes the monthly and quarterly return-flow relation between sector/industry returns and aggregate flows into funds that follow that sector/industry. Edelen and Warner (2001) conduct a similar study at a semiweekly and daily frequency. Goetzmann and Massa (2003) analyze the relation between S\&P 500 spot return and the flows to three index funds, however it is hard to generalize their results, since their sample only comprises of index funds. Our study is different from that of Warther (1995), Edelen and Warner (2001), and Goetzmann and Massa (2003) in that it examines how individual fund performance affects flows into and out of the fund.

5. As we discuss later, Johnson (2007) documents what appears to be a non-decaying lagged response in monthly net flows to prior performance (see his Table I). We suggest that the difference between our findings and Johnson's arise because we explicitly control for persistence in flows whereas Johnson does not.

6. We select this time period as electronic N-SAR filings were not mandatory until 1997.

7. Specifically, we take the end-of-period total net assets and adjust this by the fund's monthly return reported by CRSP in order to derive the next five fund size observations. Alternatively, we also scale our dollar flows by the size reported on the preceding N-SAR, as well as the average of the size reported on the preceding and current N-SAR. Our results are unchanged. Additionally, we calculate net flows following Sirri and Tufano (1998), where net flows are calculated as \{TNAt [TNAt-1 * $(1+$ Returnt)]\} / TNAt-1. We again find qualitatively similar results.

8. This is consistent with prior studies examining gross flows, such as O'Neal (1997).

9. The calculation of these variables is presented in Section 2.2.

10. We note that the CRSP reported returns are gross returns. We find qualitatively similar results using returns net of expenses.

11. The Fama French three factors and the momentum factor were downloaded from Kenneth French's website: http://mba.tuck.dartmouth.edu/pages/faculty/ken.french/data_library.html.

12. The factors are excess returns from Morgan Stanley Capital International's All Country Index, obtained from Datastream and the Broad Trade Weighted Exchange Index obtained from the St. Louis Fed Database (FRED).

13. The factors represent the term structure of interest rates, credit and liquidity spreads, exchange rates, mortgage spread and two equity market benchmarks. These factors are from CRSP, FRED and The Chicago Board of Trades.

14. Prior research suggests the relation between performance and flows is convex. To ensure that our findings are not distorted by the imposed linearity, we rerun our analysis allowing for a nonlinear performance flow relationship. We included the square of all lagged abnormal returns, as well as follow Sirri and Tufano (1998), where we rank fund performance, and split the ranking into 20-60-20 fractile buckets. Controlling for potential non-linearities does not change any of our inferences.

15. Our choice of 12 lags of flows and returns is ad hoc, but does allow us to capture potential seasonality in flows as well as a delayed response to fund performance. 
16. We note, however, that the coefficient on the nine-month lag of returns is statistically insignificant. 17. Johnson (2007) examines the relation between net flows and the fund prior six months of returns (without controlling for lagged net flows). Consistent with our column 1, he finds relatively consistent return coefficients.

18. We multiply the outflow dollar amounts by negative one. This turns outflows from positive numbers to negative numbers and, thus, makes outflows negative inflows.

19. A natural conclusion is that observed relations between annual performance and subsequent annual flows could be a manifestation of persistent responses to monthly performance. We do not pursue that possibility in this paper.

20. A detailed description of the econometric properties of ARDL models is given in Chapter 19 of Greene's (2002) textbook.

21. We focus on inflows because there is little relation between performance and outflows across the three fund types.

22. To conserve space, we do not report in figures or tables the results of our robustness checks. They are available from the authors upon request.

23. Specifically, we compute White standard errors adjusted to account for possible correlation across funds. Petersen (2006), among others, refers to these standard errors as clustered (or, Rogers) standard errors, where the clustering is across funds at a given point in time or, alternatively, across time for each fund.

24. Comprehensive references to this problem and, more generally, to the econometrics of panel data are Greene (2002), Wooldridge (2002) and Baltagi (2001).

25. Some prominent references in this area are Arellano and Bond (1991), Arellano and Bover (1995) or Ahn and Schmidt (1995).

26. The number of moment conditions is proportional to both the number of exogenous regressors and to the number of time series observations. With a dataset like ours, one is quite likely to face a bias/efficiency trade-off when using dynamic panel methods. See Baltagi, Chapter 8.7 for a thorough discussion of this point.

27. For International Equity funds and Hybrid funds, the significance patterns for net flows, inflows and outflows arrived at by clustering across funds did not change compared to those arrived at with White's correction, although the magnitude of the clustered standard errors was much larger. For Domestic Equity funds, fewer performance lags were significant for inflows and net flows with the standard errors clustered across funds than with White's.

28. Serial correlation in the coefficient estimates may be induced by fund-specific constant fixed effects. Several authors acknowledge this potential source of biases. See, for instance, Pontiff (1996), Cochrane (2001), Fama and French (2002), Graham et al. (1998).

29. By the end of 2010, these types of retirement accounts held $40 \%$ of mutual fund assets (Investment Company Institute (2011)).

30. This point is consistent with the historical evolution of studies on mutual fund advisors' ability to consistently generate abnormal returns. That line of research almost always considers growth equity funds and largely ignores the possibility of managerial ability and performance persistence in fixed-income funds (An exception is Chen et al. (2008) who look at the timing ability of bond fund managers). There is no obvious reason why, if one is in search of evidence of consistent abnormal returns that you should focus so exclusively on growth equity funds. If we assume an equal distribution of ability across the whole mutual fund environment, consistent 
abnormal returns are just as likely in fixed-income funds as they are in equity funds. Thus, it appears that finance academics, like actual mutual fund investors, may believe that ability is unequally distributed across mutual fund types.

31. Busse (2001) and Goriaev et al. (2005) are unable to find any evidence of risk-shifting within a year. Chen and Pennacchi (2009) find some evidence of changes in tracking error related to prior performance. Koski and Pontiff (1999) also find a negative relation between performance over the first part of a year and risk over the remainder of the year. Unlike Chevalier and Ellison (1997) and Brown et al. (1996), Koski and Pontiff attribute the risk to cash inflows resulting from good performance over the first part of the year.

\section{Appendix A}

We use Standard and Poor's classification to group funds into four major categories. Listed below are the categories, and the Standard \& Poor's codes and their descriptions belonging to each category:

Table 6 Domestic equity funds

\begin{tabular}{|l|l|}
\hline Standard \& Poor's Objective Code & Description \\
\hline AGG & Equity USA Aggressive Growth \\
\hline ENV & Equity USA Environmental \\
\hline FIN & Equity USA Financial Sector \\
\hline GRO & Equity USA Growth \\
\hline GRI & Equity USA Growth \& Income \\
\hline HLT & Equity USA Health \\
\hline ING & Equity USA Income \& Growth \\
\hline GMC & Equity USA Midcaps \\
\hline SEC & Equity USA Misc. Sectors \\
\hline RLE & Equity USA Real Estate \\
\hline SCG & Equity USA Small Companies \\
\hline TEC & Equity USA Technology \\
\hline UTI & Equity USA Utilities \\
\hline
\end{tabular}

Table 7 International equity funds

\begin{tabular}{|l|l|}
\hline Standard \& Poor's Objective Code & Description \\
\hline EPX & Equity Asia Pacific Excluding Japan \\
\hline EPC & Equity Asia Pacific Including Japan \\
\hline ECN & Equity Canada \\
\hline ERP & Equity European \\
\hline EID & Equity Global Emerging Markets \\
\hline EGX & Equity Global Equity Sector \\
\hline EGG & Equity Global Growth \\
\hline EGS & Equity Global Small Company \\
\hline EGT & Equity Global Total Return \\
\hline ECH & Equity Greater China \\
\hline EIG & Equity International Growth \\
\hline EIS & Equity International Small Company \\
\hline
\end{tabular}




\begin{tabular}{|l|l|}
\hline EIT & Equity International Total Return \\
\hline EJP & Equity Japan \\
\hline ELT & Equity Latin America \\
\hline
\end{tabular}

Table 8 Hybrid funds

\begin{tabular}{|l|l|}
\hline Standard \& Poors Objective Code & Description \\
\hline FLG & Asset Allocation Global Flexible \\
\hline BAL & Asset Allocation USA Balanced \\
\hline FLX & Asset Allocation USA Flexible \\
\hline IMX & Asset Allocation USA Income \\
\hline CPF & Asset Allocation USA Preferred \\
\hline EPR & Asset Allocation USA Principle Return \\
\hline
\end{tabular}

\section{References}

Ahn S, Schmidt P (1995) Efficient estimation of models for dynamic panel data. J Econ 68:5-28

Alexander GJ, Cici G, Gibson S (2007) Does motivation matter when assessing trade performance? An analysis of mutual funds. Rev Financ Stud 20:125-150

Arellano M, Bond SR (1991) Some tests of specification for panel data: Monte-Carlo evidence and an application to employment equations. Rev Econ Stud 38:277-297

Arellano M, Bover O (1995) Another look at instrumental-variable estimation of error-components models. J Econ 68:29-52

Baltagi BH (2001) Econometric analysis of panel data. Wiley, New York

Bergstresser D, Poterba J (2002) Do after-tax returns affect mutual fund inflows? J Financ Econ 63:381414

Berk JB, Green RC (2004) Mutual fund flows and performance in rational markets. J Polit Econ 112:12691295

Brown KC, Harlow WV, Starks LT (1996) Of tournaments and temptations: an analysis of managerial incentives in the mutual fund industry. J Finance 51:85-110

Busse JA (2001) Another look at mutual fund tournaments. J Financ Quant Anal 36:53-73

Chen Hsiu-lang, Pennacchi GG (2009) Does prior performance affect a mutual fund's choice of risk? Theory and further empirical evidence. J Financ Quant Anal 44:745-775

Chen $\mathrm{Y}$, Ferson W, Peters $\mathrm{H}$ (2008) Measuring the timing ability of fixed income mutual funds, working paper, Boston College

Chevalier J, Ellison G (1997) Risk taking by mutual funds as a response to incentives. J Polit Econ 105:1167-1200

Christoffersen S, Evans R, Musto D (2005) The economics of mutual fund brokerage: evidence from the cross section of investment channels, working paper

Cochrane JH (2001) Asset pricing. Princeton University Press, New Jersey

Cohen L, Schmidt B (2009) Attracting flows by attracting big clients. J Finance 64:2125-2151

Del Guercio D, Tkac PA (2002) The determinants of the flow of funds of managed portfolios: mutual funds vs. pension funds. J Financ Quant Anal 37:523-557 
Del Guercio D, Tkac PA (2007) Star power: The effect of Morningstar ratings on mutual fund flows, working paper, University of Oregon

DeSantis G, Gerard B (1998) How big is the risk premium for currency risk. J Financ Econ 49:375-412

Dumas B, Solnik B (1995) The world price of foreign exchange risk. J Finance 2:445-479

Edelen RM (1999) Investor flows and the assessed performance of open-end mutual funds. J Financ Econ 53:439-466

Edelen RM, Warner JB (2001) Aggregate price effects of institutional trading: a study of mutual fund flow and market returns. J Financ Econ 59:195-220

Fama E, French KR (2002) Testing tradeoff and pecking order predictions about dividends and debt. Rev Financ Stud 15:1-33

Fama EF, MacBeth JD (1973) Risk, return and equilibrium: empirical tests. J Polit Econ 81:607-636

Fant F, O'Neal E (2000) Temporal changes in the determinants of mutual fund flows. J Financ Res 23:353-371

Goetzmann WN, Massa M (2003) Index funds and stock market growth. J Bus 76:1-28

Goriaev A, Nijman TE, Werker BJM (2005) Yet another look at mutual fund tournaments. J Empir Finance 12:127-137

Graham J, Lemmon M, Schallheim J (1998) Debt, leases, taxes and the endogeneity of corporate tax status. J Finance 53:131-162

Greene WH (2002) Econometric analysis. Prentice Hall, New Jersey

Investment Company Institute (2006) Fact book. Investment Company Institute, Washington, D.C

Investment Company Institute (2009) Fact book. Investment Company Institute, Washington, D.C

Investment Company Institute (2011) Fact book. Investment Company Institute, Washington, D.C

Ivkovich Z, Weisbenner SJ (2006) 'Old' money matters: the sensitivity of mutual fund redemption decisions to past performance, working paper, University of Illinois

Johnson WT (2007) Who monitors the mutual fund manager, new or old shareholders?, working paper, University of Oregon

Keswani A, Stolin D (2008) Which money is smart? Mutual fund buys and sells of individual and institutional investors. J Finance 63:85-118

Koski JL, Pontiff J (1999) How are derivatives used? Evidence from the mutual fund industry. J Finance $54: 791-816$

Nanda V, Jay Wang Z, Zheng Lu (2009) The ABCs of mutual funds: on the introduction of multiple share classes. J Financ Intermediation 18:329-361

O’Neal E (1997) How many mutual funds constitute a diversified mutual fund portfolio? Financ Anal J 53:37-46

Patel J, Zeckhauser RJ, Hendricks D (1994) Investment flows and performance: evidence from mutual funds, cross-border investments and new issues. In: Satl R, Levitch R, Ramachandran R (eds) Japan, Europe and the International financial markets: analytical and empirical perspectives. Cambridge University Press, New York

Petersen MA (2006) Estimating standard errors in finance panel data sets: comparing approaches, working paper, Northwestern University

Pontiff J (1996) Costly arbitrage: evidence from closed-end funds. Q J Econ 111:1135-1151

Sirri ER, Tufano P (1998) Costly search and mutual fund flows. J Finance 53:1589-1622

Warther VA (1995) Aggregate mutual fund flows and security returns. J Financ Econ 39:209-235

Wooldridge J (2002) Econometric analysis of cross section and panel data. MIT Press, Cambridge 